\title{
The impact of the West Sumatran regional recording industry on Minangkabau oral literature
}

\author{
SURYADI
}

\begin{abstract}
Due to the emergence of what in Indonesian is called industri rekaman daerah 'Indonesian regional recording industries', which has developed significantly since the 1980s, many regional recording companies have been established in Indonesia. As a consequence, more and more aspects of Indonesian regional culture have appeared in commercial recordings. Nowadays commercial cassettes and Video Compact Discs (VCDs) of regional pop and oral literature genres from different ethnic groups are being produced and distributed in provincial and regency towns, even those situated far from the Indonesian capital of Jakarta. Considering the extensive mediation and commodification of ethnic cultures in Indonesia, this paper investigates the impact of the rise of a regional recording industry on Minangkabau oral literature in West Sumatra. Focussing on recordings of some Minangkabau traditional verbal art genres on commercial cassettes and VCDs by West Sumatran recording companies, this paper attempts to examine the way in which Minangkabau traditional verbal art performers have engaged with electronic communication, and how this shapes technological and commercial conditions for ethnic art and performance in one modernizing society in regional Indonesia.

KEYWORDS

Oral literature, oral tradition, traditional verbal art, media technology, Minangkabau, West Sumatra, regional recording industries, cultural mediation, representation of traditional culture, commodification of cultural practices, cassette, VCD.
\end{abstract}

\footnotetext{
SURYADI is a lecturer in Indonesian studies at Leiden Institute for Area Studies / School of Asian Studies, Leiden University, and a PhD candidate at Leiden University. His research interests are oral tradition, literary life, and media culture in Indonesia. He is the author of "The image of radio technology in modern Indonesian literature" in Lalita Sinha (ed.), Rainbow of Malay Literature and Beyond; Festschrift in Honour of Professor Dato' Dr. Md. Salleh Yaapar. Penang: USM Press (in press) and "Transnasionalisasi muzik Indonesia: Makna kultural dan fungsi sosiopolitik resepsi muzik pop Minang di Malaysia", Wacana Seni; Journal of Arts Discourse, Universiti Sains Malaysia, Penang 6 (2007), pp. 1-30. Correspondence in connection with this paper should be addressed to: s.suryadi@hum.leidenuniv.nl.
}

(C) 2010 Faculty of Humanities, University of Indonesia 


\section{INTRODUCTION}

Over the last two decades Indonesian regional recording industries have developed significantly. ${ }^{1}$ Two media technologies which have been used extensively by the regional and national recording industries ${ }^{2}$ in the country are cassette and Video Compact Disc (VCD). Cassette technology entered Indonesian in the early 1970s (Sutton 1985; Yampolsky 1987), replacing the gramophone ${ }^{3}$ which had been introduced into the country since the late of nineteenth century. Along with the rise of cassette consumption in Indonesia, an active recording industry emerged, conditioned by the new flows of capital that entered the country through the agency of the New Order regime (Weintraub 2004: 165). Cassettes remained dominant in Indonesia up to the late 1990s, when they were strongly challenged by the audio-visual technology of VCD. Geographically, the products of Indonesia's regional recording industries have also been distributed outside their local ethnic origin, along with the migration of many ethnic groups in Indonesia, nationally and regionally. The VCD, more intensively than the cassette, has been used to mediate aspects of many ethnic cultures in Indonesia, which indeed brings about extensive commodification of local culture. A study on Nusantara regional recording industries carried out by Pusat Penelitian Kemasyarakatan dan Kebudayaan-Lembaga Ilmu Pengetahuan Indonesia (Centre of Social and Cultural Studies, The Indonesian Academy of Science) in cooperation with the Ford Foundation in 1999 has shown that regional recording companies have emerged in the majority of Indonesian provinces (Bangun et al. 1999). Since the early 2000s such companies have produced VCDs as well as cassettes representing "regional" materials (Barendregt and Van Zanten 2002; Yampolsky 2003). In Indonesian it is called pop daerah (regional pop), a "label given to musics in regional languages or dialects that contain nontraditional elements" (Wallach 2008: 34). Almost every ethnic group in Indonesia has its own pop music which is now available on commercial recordings, for example, from pop Kampar in Riau Province to pop Buton in Southeast Sulawesi Province. Even small ethnic groups like the Nagi in Flores have their own pop music cassettes and VCDs (Bos 2005: 152-155). As Yampolsky has mentioned (2003),

I would like to thank Bernard Arps for his comments and suggestions for improving this paper, and Ian Proudfoot for his English corrections. Many thanks also go out to Andiko Sutan Mancayo and Nigel Phillips who have provided some materials used in this paper. The content and any errors in this paper are my own responsibility.

2 The term "regional recording industries" or industri rekaman daerah in Indonesian used in this paper refers to the economic activities of making commercial recordings with regional contents using regional mother tongues, produced by recording companies situated in provincial towns which are conducted mostly by ethnicity-based local entrepreneurs for specific ethnolinguistic markets. Conversely, the term "national recording industry" or industri rekaman nasional in Indonesian, refers to such activities on the national level, conducted by recording companies sometimes in cooperation with international partners. The commercial recordings they produced use the Indonesian language (bahasa Indonesia) and are appreciated nation-wide.

A Dutchman named De Greef was the first to demonstrate the phonograph to the public of Java around 1882 (Brooshooft 1892). On the arrival and consumption of phonograph or gramophone in Indonesia, see Suryadi $(2006,2007 a)$. 
such commercial VCDs, which contain regional genres, can be found almost everywhere in Indonesia, from the westernmost Indonesian town of Banda Aceh to its easternmost town of Merauke. In proportion, regional commercial cassettes and VCDs capture 40 percent of their market segment in Indonesia (Sopiann 2002: 40).

Obviously, the rapid development of Indonesian regional recording industries has also influenced ethnic oral literature. ${ }^{4}$ Thus for example, we can now find commercial VCDs of the Butonese traditional verbal art kabanti in Southeast Sulawesi and of the Sundanese rod-puppet theatre wayang golek in West Java. Such cultural representations through electronic media have also involved Minangkabau traditional verbal art, which has been stimulated by the West Sumatran recording industry. This industry is the most prominent regional recording industry in Sumatra and has developed significantly over the last two decades. Agusli Taher (2008) has noted that there were 65 local producers in West Sumatra in 2008, 33 recording studios, 16 production houses, and hundreds orgen tunggal (single keyboard) business, making West Sumatra one of Indonesia's biggest music industry centres after Jakarta. Though the predominant product of the West Sumatran recording companies is pop Minang (Barendregt 2002; Suryadi 2003a), they also have shown enthusiasm in producing Minangkabau traditional verbal art genres, both in cassette and VCD format. As competition among the recording companies increases, there has been extensive mediation of Minangkabau culture, including its oral literature. This, in turn, impacts structurally and sociologically on the traditional art forms.

The most significant development of modern media in Indonesia has been the emergence of the "cassette culture", to borrow Manuel's term (1993), which has led performers of the traditional verbal art to engage with modern electronic communication. Nevertheless, study of oral literature in Indonesia seems to have escaped the attention of scholars of modern electronic media. Instead, oral literature is considered only as the repertoires of traditional rural society untouched by modern media technologies. At most, Indonesian researchers in this field examine the impacts of print media on traditional oral literature, a topic commonly discussed in seminars such as those frequently organized by ATL (Asosiasi Tradisi Lisan, Oral Traditions Association ${ }^{5}$ ). In such academic forums, one often hears the anxiety that the committing oral literature genres to written books will degrade its existence. But other parties oppose this notion, arguing that transferring the texts of oral literature to

4 In this paper I use the term "oral literature" which is translated into Indonesian as sastra lisan. Though this term has sometimes been disputed on the ground that it is self-contradictory if the original etymology of "literature" (connected with litterae, letters) is borne in mind, the term has been widely accepted (Finnegan 1977: 16). In this paper I also use the term "traditional verbal art" as a substitute for the term "oral literature", because the objects we discuss here are ethnic cultural expressions expressed in oral language art works (Dutch: mondelinge taalkunst). These cultural expressions of course strongly engage with Minangkabau oral tradition.

The recent ATL meeting, entitled The International Seminar and Festival on Oral Traditions VI, was held on 1-3 December 2008 at Wanci, Wakatobi Regency, South-East Sulawesi, Indonesia. 
paper can save them from extinction.

As the regional recording industries in Indonesia have a significant impact on ethnic cultures, the study of Indonesian oral literature should, in my opinion, expand by analysing the influence the modern electronic media on them. In this paper I will recount the historical mediation of Minangkabau traditional verbal art genres and the continuing process of this mediation in the current electronic communication era. Furthermore, I will discuss the production, the circulation, and the consumption of these electronically mediated genres, and look at how far the representation of oral literature genres in this modern mediation affects the intrinsic aspects (such as narrative, story-line, language, and artistic style) of Minangkabau oral literature.

\section{MINANGKABAU ORAL LITERATURE GENRES}

There are many genres of Minangkabau oral literature or verbal art, which in regional and national terminology is called kesenian tradisi (traditional art). Amir, Zuriati, and Khairil Anwar (2006), who mapped Minangkabau oral literature genres throughout West Sumatra, list some 50 genres. Apparently their book does not record some other genres, such as luambek in Pariaman regency (Pätzold 2004), the tiger-capturing song dendang managkok-marinda harimau $^{6}$ in Pasaman (Kartomi 1972), and batintin in Rao-Rao, Tanah Datar Regency (Susanti 1992; Mulyadi et al. 2008: 22-26). The major genres have engaged with electronic media as consequence of the extensive consumption of media technologies in Minangkabau society since the early 1980s.

In the following section I will briefly survey the major genres of Minangkabau oral literature which have been recorded by West Sumatran recording companies on commercial cassettes and VCDs. They include rabab Pariaman, indang, rabab Pesisir Selatan (or rabab Pasisia), dendang Pauah, sijobang, saluang (or bagurau), salawat dulang, randai, and pidato adat dan pasambahan. Some genres exist in many parts of West Sumatra while others are specific to the particular regions with texts strongly influenced by a particular dialect of the Minangkabau language. Some genres recite $k a b a^{7}$

6 On the tiger-capturing and magic charms used in the Minangkabau highlands, see Van der Toorn (1879: 452-454).

$7 \quad K a b a$ are Minangkabau folktales consisting of narratives which present the social and personal consequences of either ignoring or observing the ethical teachings and the norms embedded in the adat (see Bakar et al. 1979). Traditionally, kaba are recited by the storytellers (tukang kaba), in the form of several genres of Minangkabau oral literature such as rabab Pariaman, rabab Pesisir Selatan, sijobang, basimalin, bataram, dendang Pauah, and open air theatre randai. The storyteller recites the text by singing to various tunes, while accompanying himself on traditional music instruments such as the rebab (spike-fiddle, violin), different sorts of bamboo flutes (such as saluang Pauah, bansi), adok (a sort of tambourine), kotak korek api (matchbox), kucapi (steel-stringed zither), pupuik (pipe), and talempong (small kettle gong). The text is composed in lyrical prose or pantun (verse). By content, kaba can be categorized into two groups: classic and modern. The classic kaba are set in the traditional kingdoms with main characters who have supernatural power, whereas modern kaba represent the modern Minangkabau social environment in the post-colonial era with common people as the main characters (Junus 1984). The title of a kaba is usually taken from the name of its protagonist(s), such as "Kaba Bujang Paman", "Kaba Magek Manandin", "Kaba Siti Kalasun" (see Djamaris 2004), and "Kaba Zamzami dan Marlaini" (see Suryadi 1993a, 
and other genres comprise sung traditional verses such as pantun and syair.

The former two genres, rabab Pariaman and indang, exist in Pariaman district of the north-west coast of West Sumatra Province. Often telling a classic $k a b a^{8}$ (see note 7), rabab Pariaman is usually performed by a solo singer, accompanied by a small three-stringed lute called rabab galuak (galuak = coconut shell, which is used for the body of the instrument) (Witnayetti 1992; Suryadi 1996, 1998). Indang is performed by a troupe of 8 to 22 performers, accompanied by a small frame drum which is called rapa' $i$ (Kartomi 1986). It is performed in the format of a contest in which three troupes face each other (one troupe acts as the host). The essence of indang is bersilat lidah, which means literally "fight with the tongue": the performers of each group try to pick out and tease the others by using a literary register of Minangkabau language full of allusion, allegory, metaphor, and aphorisms. Indang does not tell kaba stories. A plenary indang performance involves 21 troupes over fourteen nights, as usually presented in nagari (Minangkabau village confederacy; the indigenous political unit) festivities or at the festivities celebrating the installation of panghulu (Sulaiman 1989/1990; Suryadi 1994; Ediwar 2003, 2007).

Rabab Pesisir Selatan and dendang Pauah exist locally in the lowland of West Sumatra's west coast. As suggested by its name, rabab Pesisir Selatan is current exists in Pesisir Selatan district in West Sumatra south-west coast, but now seems to have gained popularity in other places such as Padang and Solok. Performed by a solo singer (sometimes with his pupils), rabab Pesisir Selatan tells modern kaba, accompanied by the rabab (violin) (Suryadi 1993a; Arni 1995; Koto 2003). ${ }^{9}$ Dendang Pauah is found in the outskirts of Padang in Pauah district and surroundings. It also tells kaba in modern

Wieringa 1997), but sometimes the title refers to the place of origin of the protagonist(s), such as "Kaba Kejadian di Batipuah, Padang Panjang" (The Story of Occurence in Batipuah, Padang Panjang), "Kaba Urang Bukiktinggi" (The Story of Bukittinggi People), and "Kaba Urang Bonjo" (The Story of Bonjol People) (Suryadi 1993b: 20).

The only modern kaba narrated in rabab Pariaman is "Siti Baheram". This story is based on a real tragedy: the robbery and murder of a rich woman named Siti Baheram in the Pariaman village of Sungai Pasak on 11 November 1916. The suspects were a gambler named si Joki, who was one of the victim's relatives, and his friend named Si Ganduik (Sinar Sumatra, 16 November 1916). The Dutch colonial government then punished si Joki by hanging him and Si Ganduik was sentenced to prison for several years. Since then this tragic story had been very famous in Pariaman and surroundings. Thus for example, the Orang Alam Minangkabau Press owned by Mahyuddin Datuk Sutan Maharaja, one of the leading adat defenders countering Minangkabau Moslem reformists like Syekh Ahmad Khatib alMinangkabauwi, published Sjair Cerita SITI BAHERAM: Pemboenoehan jang ngeri di Pariaman I en II (The Poem of Siti Baheram: A horrifying murder in Pariaman, vol. 1 and 2) (Soenting Melajoe, 28 January 1921). In 1964 it was also published by Pustaka Arga in Bukittinggi with the copyist Sjamsoeddin St. Radjo Endah, assisted by Irsda Muljana (It was reprinted in 1976 and 2004). This kaba has also been adapted into plays performed by theatre groups from West Sumatra. The pantun on the Siti Baheran murder is always sung in dendang Kim, a typical Pariaman song genre, such as found on VCD Karaoke KIM-Pantun \& Lagu: 'Raja Dolli' by S. Effendy Koto (Padang: Tanama Records 2002).

9 Linguistically, rabab Pesisir Selatan's text feels modern in terms of word choice and phrases. Unlike rabab Pariaman, the language of rabab Pesisir Selatan text is rather poorly endowed with lateral talk, allusion, and aphorisms. 
style. In this genre, the text is composed in verse form (see description below) full of allegories, metaphors, and allusions. It is performed by two performers (usually male): a singer (tukang dendang) and a flute-player (tukang saluang) who plays a bamboo flute called saluang Pauah (Suryadi 1993b).

Sijobang is found in Lima Puluh Kota Regency at West Sumatra highlands. Its performance is carried out by a solo singer (tukang sijobang) accompanied either by the rhythmic tapping of a half-empty matchbox or by the strumming of the steel-stringed kucapi. Sijobang always relates the adventures and romantic exploits of a hero known as Anggun Nan Tongga Magek Jabang (Phillips 1981). ${ }^{10}$

The five remaining genres, saluang, salawat dulang, randai, and pidato adat dan pasambahan, are found in many parts of West Sumatra, but sometimes with local names ${ }^{11}$. The Minangkabau saluang or bagurau involves humorous pantun-singing. Bagurau is performed by a troupe usually consisting of one flute-player (male) and one or two singers (female) (Firman 1992). The lyric of the songs, which evokes the atmosphere of village life and serves as a vehicle for teaching morals, stirs the audience's emotions and provokes a nostalgic mood audience. As it is usually performed at night, the saluang performance is also known as malam bagurau (evening of jollity).

Salawat dulang (sometimes spelled shalawat dulang, salawaik dulang, or salawat talam) is a religious art form for "remembering God" (Kartomi 1986). It is performed by two male singers, who accompany themselves by rhythmic beating on round brass trays (dulang or talam), as opposed to frame drums. The text, which is recited to the beat of a round brass tray, contains Islamic teachings. Salawat dulang essentially perform 'fights with the tongue' (like indang), but the debated topics deal with religious matters. The performance is set up as a contest between two troupes who sing by turn. ${ }^{12}$ Salawat dulang is very popular among the Minangkabau, since this ethnic group embraces Islam (Amir 1996; Bahar 1997).

Randai is a Minangkabau open air folk theatre. This type of traditional drama is found in many parts of West Sumatra. Previously almost every nagari (Minangkabau village confederacy; the indigenous political unit) had its own

10 On the printed versions of the "Kaba Anggun Nan Tongga Magek Jabang", see Bagindo Kajo (1925), Djamin and Tasat (1934) and Mahkota (1962). For the Malay version of this story, see Winsted (1914).

11 In Pariaman, for example, salawat dulang is called salawat talam or batalam, and in Tiku district of Pariaman the local name for randai is simarantang (see Phillips 1981: 5).

12 Reflecting its essence as 'fight with the tongue' verbal art, salawat dulang troupes have pretentious names, such as "Kilek Barapi" (Blazing Thunderbold), "Piriang Talayang" (Flying Suicer), "Arjuna Minang" (Minang Arjuna), "Gurun Sahara" (Sahara Desert), "Mustang" [the name of a fighter plane that well-known during the World War Two], "DC 8" [the name of an aircraft produced by Boeing], "Langkisau" [Minangkabau world for whirlwind], "Peluru Kendali" (Guided Missile) and "Garuda Minang" (Minangkabau Garuda; garuda is a mythical bird, mounted by God Vishnu in Hindu religion, which is used as the official seal of the Republic of Indonesia), which are strong, deft, and threatening in their referential meanings (Amir 1996). One pair of performers asks questions (in gurindam or syair forms), or members of the audience may ask the competitors questions, ranging from the religious to the clairvoyant, seeking advice or information (Kartomi 1986). 
randai troupe. Unlike other genres, randai is a high-spirited combination of dance, martial arts, dialogue, and music in a performance of Minangkabau kaba, accompanied by talempong, as well as other gongs, drums and pupuik, which produce a static texture consisting of interlocking rhythms (Kartomi 1981; Pauka 1998; Latrell 1999).

Pidato adat dan pasambahan is ceremonial oration or speech-making using a highly standardized literary register of the Minangkabau language, heavy with analogy, metaphor, allegory, and simile. It is presented on the occasion of events such as wedding parties or the festivities celebrating the installation of a new penghulu (head of matrilineal unit). The essence of this genre is also a "fight with the tongue" (see Van Hasselt 1883; Kasih 2008). Though the genre exists in many parts of West Sumatra, its textual composition differs between the Minangkabau highlands (darek) and the western coastal lowlands (rantau, literally "place of migration").

The texts of all these genres, whether containing kaba or not, are touched in various lyrical styles with variety of rhythms. The texts of rabab Pariaman, rabab Pesisir Selatan, sijobang, randai, and pidato adat dan pasambahan are in lyrical prose, but of course rhyming pantun are also used, usually to introduce the story, to mark turning-points in the plot, and to end the singing ${ }^{13}$ (Navis 1984: 247-249; Phillips 1991: 81). On the other hand, the texts of dendang Pauah, indang, saluang and salawat dulang are composed in verse forms - the former three in pantun form and the latter in syair form. In all these Minangkabau traditional verbal art genres, each genre has its own vocabularies and idioms, giving rise to a wide variety of local traditions in West Sumatra.

The Minangkabau oral literature genres mentioned above are traditionally performed on public occasions of celebration, such as at marriage festivals, at celebration of Prophet Muhammad's birthday in surau (religious shrines), at the nagari festivals (alek nagari), and the festivities celebrating the installation of a new penghulu (male village leader; head of matrilineal unit). They are also often performed to gather money for building public facilities like school and village halls (balai desa). They are usually performed at night, after Isya prayer (around 9 p.m.) running through to daybreak (around 5 a.m.). For that reason, the Minangkabau verbal art genres are called "night music of West Sumatra" by Philip Yampolsky, who made a series CD recordings of saluang, dendang Pauah, and rabab Pariaman in 1994, supported financially by Smithsonian Institution. ${ }^{14}$

\section{EARLY RECORDINGS OF MINANGKABAU VERBAL ART}

As a prelude to discussing the current mediation of Minangkabau oral literature in cassette and VCD format, I will say something about the historical

13 In sijobang performance, for example, pantun are used in three ways: as pantun pasambahan (introductory pantun) before the story, to mark the beginning, resumption or end of a stint of singing, and as part of dialogue and narrative itself (Phillips 1979: 12).

14 See http://www.folkways.si.edu/projects_initiatives/indonesian/liner_notes/ volume06. html (accessed 5-3-2008). 
appearance of the first Minangkabau verbal art recordings during the era of the "talking machine" (gramophone). ${ }^{15}$ In Sumatra, commercial gramophone recordings of Batak and Minangkabau music seem to have appeared in the 1930s, produced by Chinese-owned recording companies situated in Java. Some Minangkabau verbal art genres also appeared on commercial gramophone discs at this time. Toko Anti Mahal in Fort de Kock (Bukittinggi) issued the Angsa brand disc (Tjap Angsa) which circulated exclusively in Sumatra. ${ }^{16}$ The early recordings of Minangkabau oral repertoires contained traditional songs, Islamic songs of gambus music (including recitations of the Qur'an), and the Minangkabau oral literature genre of saluang jo dendang (flute and chanting), other name for saluang or bagurau.

In 1939, for example, the Minangkabau saluang jo dendang was available on Odeon Gadjah disc brand, produced by Toko Minangkabau in Fort de Kock. Referred to as "Njanjian Minangkabau Asli" (the authentic Minangkabau songs), the saluang jo dendang appeared in two discs: the first disc contained "Lagoe Simarantang" and "Lagoe Moenah Kajo" on the one side and "Lagoe tangisan oerang Batoe Sangka" on the other side. The chanter (tukang dendang) of this disc was Djamarih from Batagak Bukittingi, the flute players (toekang saloeang) were Mak Pono from Singgalang and Datoek Panggak from Sungai Buluah, while the whistle player (toekang pupui') was Mak Toelah from Koto Tuo. The first side of the second disc contained "Lagoe Membuaikan Anak" and "Lagoe Siti Baheram" on either side. The chanter was Noeriahsjam from Suliki, Payakumbuh. ${ }^{17}$ A well-known saluang performer, Syawir Sutan Mudo, recalled that his bagurau performances had recorded on 78-rpm gramophone discs before being re-recorded on cassettes in 1972 (Yurnaldi 2000).

It is likely that Minangkabau kaba were also recorded on gramophone discs $^{18}$, which was circulated in West Sumatra as well as in the rantau. In Batavia, for example, the main distributor for kaba commercial discs was Toko Delima in Batavia Centrum (Salim 1935: back cover) (Figure 1). But Salim's book gives no detailed information which might identify the genres of Minangkabau oral literature that were recorded. No copies of the discs can be found now.

15 Apparently, the people of Padang had encountered recording technology, that is phonograph, in the late of nineteenth century, as shown by an advertisement stating that: Edison's, Home Phonograaf. Wordt bij geleegenheid der van kroningsfeesten te Padang. Ten gehoore gegeven (Edison's, Home phonograph, will be demonstrated on the occasion of the Coronation Festivities [of Dutch Princess Wilhelmina] in Padang) (Sumatra-Courant, 30 August 1898). This is shortly after the device began to be advertized for sale in the pages of the newspapers of Java (see Suryadi 2007a).

16 See Sinar Sumatra 22 September 1939 and subsequent dates.

17 See Sinar Sumatra 6 July 1939.

18 However, since the late nineteenth century, the Minangkabau oral kaba had been written in manuscripts using Arab-Malay (Jawi) script. Some Dutch teachers appointed to West Sumatra also published some kaba and translated them into Dutch (see for example, Van der Toorn 1886; Van Ophuijsen 1896). Today many kaba are still published in pocket-book format by local publishers in West Sumatra, like Kristal Multimedia in Bukittinggi. For more on the influence of printing toward Minangkabau kaba, see Junus $(1984,1994 b)$. 


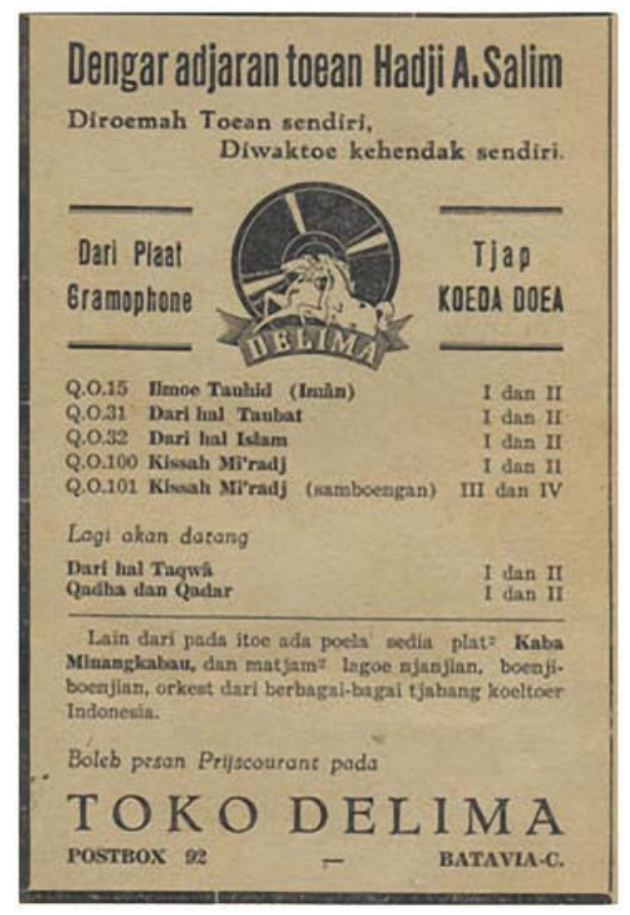

Figure 1. Advertisement of Minangkabau kaba and religious sermons commercial discs delivered by Hadji Agoes Salim (Sources: Salim 1935: back cover).

\section{MINANGKABAU ORAL LITERATURE ON CASSETTE AND VCD}

The recording of many regional oral literature genres in Indonesia was undoubtedly stimulated by the emergence of regional recording industries in the early 1970s, which led to bring rise in the consumption of recordings in cassette format across the country. This new industry developed first in Java and Bali (see Toth 1980; Sutton 1985; Williams 1989/1990; Darma Putra 2004), ${ }^{19}$ later extending to other outer islands. ${ }^{20}$ In Sumatra, regional recording companies first established in Padang and Medan in the early 1970s began producing commercial cassettes of Minangkabau and Batak popular songs and traditional verbal art genres (Rodgers 1986; Barendregt 2002; Suryadi 2003a).

According to Umar Junus, in 1971 a small private company in Padang produced the rabab Pesisir Selatan commercial cassettes of "Kaba Hasan Surabaya" (The Story of Hasan of Surabaya), performed by Syamsuddin (Junus 1994a: 410; 1994b: 109). Evidently this was a pioneer of a Minangkabau oral literature genre earlier in cassette format for commercial purposes. Over the following years, in step with the increased consumption of cassette in

19 Java and Bali were exceptionally favourable because the prominent towns of the both islands, such as Jakarta, Surabaya, Semarang, and Denpasar since the beginning were the main gateways for entering foreign technology, including recording technology, into Indonesia (see Suryadi 2006).

20 See, for example, Sutton (2002) on the regional recording industry in South Sulawesi and Postill (2006) on the regional recording industry in North Borneo. 
Indonesia, the number and variety of commercial recordings of Minangkabau oral literature also increased. Most such recordings have produced by two leading West Sumatran recording companies situated in Padang: Tanama Records $^{21}$ and Sinar Padang Records ${ }^{22}$. Both companies were established in the early 1970s. Since the late of the 1980s some other new competitors, such as Pelangi Records, Minang Records, and Talao Records, have also produced Minangkabau oral literature commercial cassettes and VCDs.

In the following paragraphs I will describe briefly the commercial cassettes and VCDs of Minangkabau oral literature genres made by West Sumatran recording companies. However, not all recordings ever released by the West Sumatra recording companies are listed simply because the companies lack good archives. Consequently, I have not been able to identify all the recordings of Minangkabau oral literature genres they have produced.
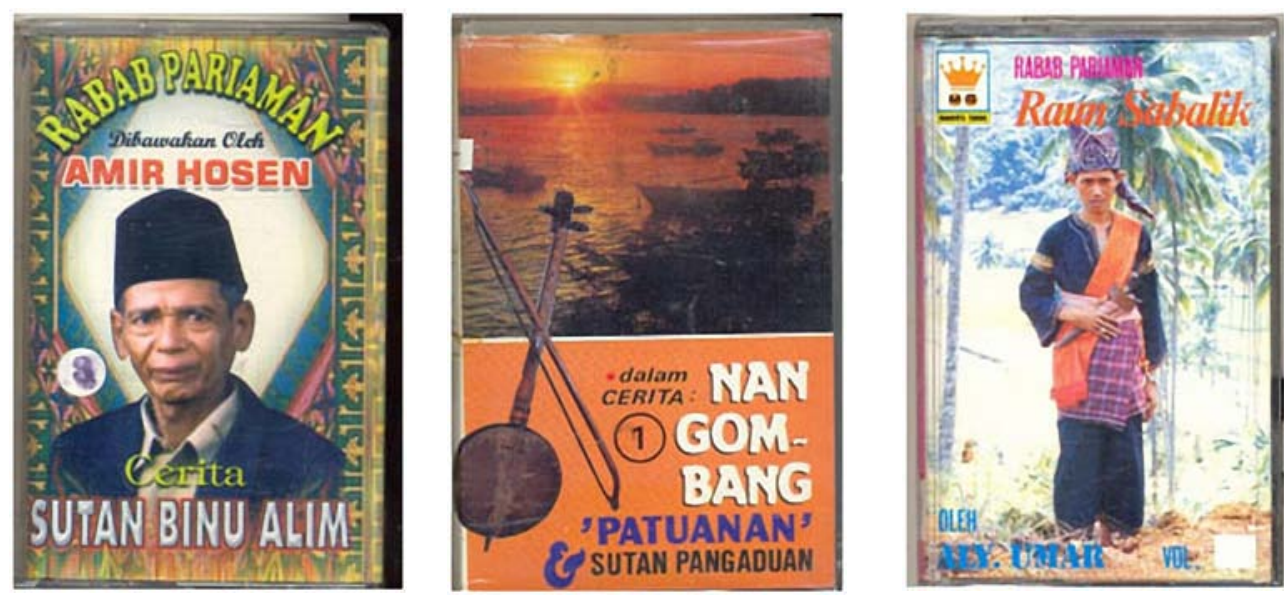

Figure 2. Rabab Pariaman cassette covers.

Rabab Pariaman commercial recordings have been mostly produced by Tanama Records and released only in cassette format, performed by the singer Amir Hosen, Aly Umar, and Bagindo Sukiman. As examples, Tanama Records produced "Jalan Kuliliang Bilang Nagari" (Traveling around Count the Villages; 2 cassettes); "Kaba Sutan Binu Alim” (The Story of Prince Binu Alim; 6 cassettes; Figure 2); and "Kaba Nan Gombang Patuanan \& Sutan Pangaduan" 23 (The Story of the Handsome Patuanan and Prince Pangaduan; 20 cassettes; Figure 2), all performed by Amir Hosen. Aly Umar's performances

${ }^{21}$ I have to note here that generally the West Sumatran recording companies write 'record' instead of 'records' in their last names: Balatif Record instead of Balatif Records, Minang Record instead of Minang Records, and Pitunang Record instead of Pitunang Records-just to mention a few names.

22 On the cover of cassettes and VCDs produced by this company, its name is written only as 'Sinar Padang'.

${ }_{23}$ In Pesisir Selatan regency this story is well known as "Kaba Sutan Pangaduan" Sutan Pangaduan is Gombang Patuanan's son-and is told in the bataram performance in the nagari of Batuhampa (Zuriati 2006). 
were entitled "Kaba Siti Baheram" (The Story of Siti Baheram; 5 cassettes; see note 8), "Kaba Sutan Gando Hilang" (The Story of Prince Gando Hilang; 5 cassettes), and "Raun Sabalik24" (Travelling Around; 1 cassette; Figure 2) - a version of Amir Hosen's "Jalan Kuliliang Bilang Nagari". Also with Tanama, the singer Bagindo Sukiman recorded "Kaba Si Untuang Sudah" (The Story of Untuang Sudah; 7 cassettes).
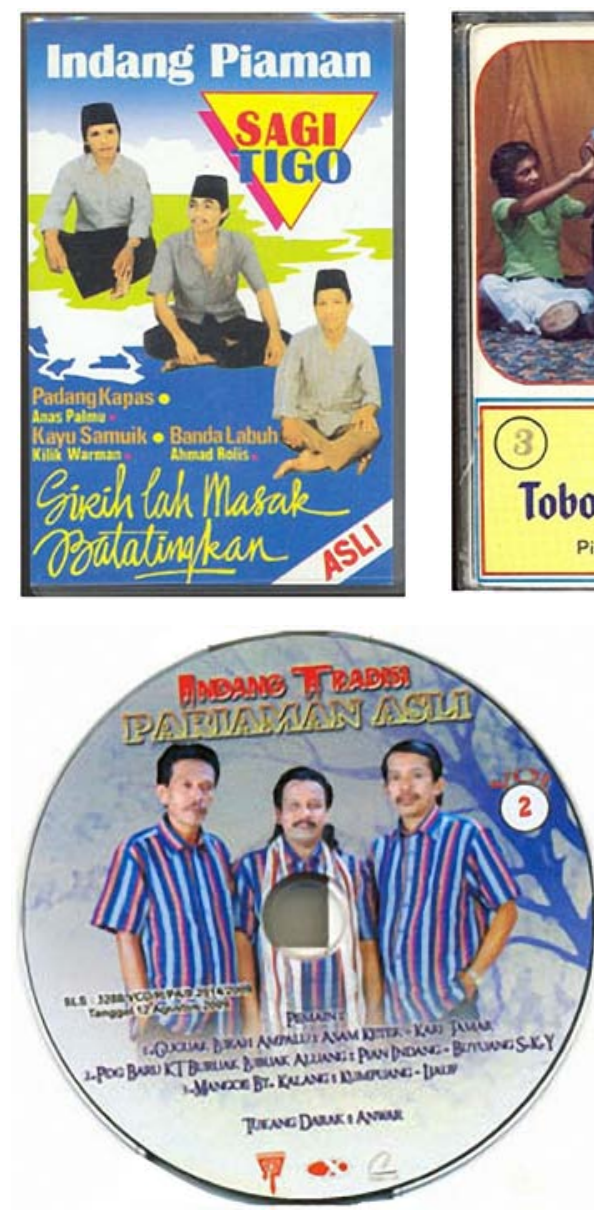
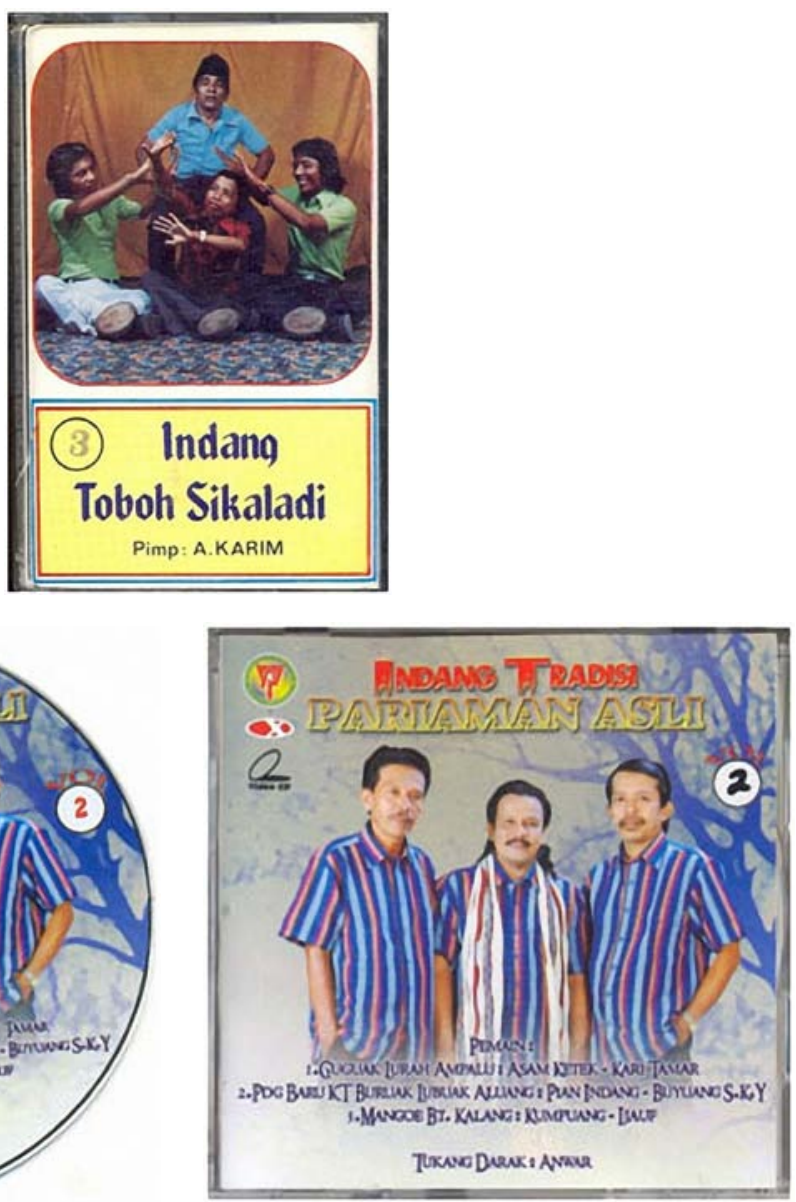

Figure 3. Indang cassette covers (above); indang VCD and its cover (below).

Indang commercial recordings have been released on cassette as well as VCD. For example, Tanama Records produced the cassettes of an indang troupe from Toboh Sikaladi village of Pariaman Regency (4 cassettes; Figure 3). The troupe was famous for the dexterity of its performers, who were very clever in playing rapa'i, the musical instrument used for accompanying the performance, for their brightness in answering all the questions posed by their opponent troupes, and for the verbal pitfalls they fire off. Tanama also

24 "Raun Sabalik" performed by Aly Umar and "Jalan Kuliliang Bilang Nagari" performed by Amir Hosen do not tell kaba; they give accounts of the nagaris situated in Minangkabau western rantau, with their unique local culture and the specific characters of their people. 
produced "Indang Piaman Sagi Tigo" (Pariaman Indang Triangle; 3 cassettes), performed by three troupes from Padang Kapeh, Kayu Samuik, and Banda Labuah villages, all situated in Padang Pariaman regency (Figure 3), and "Sejarah Syekh Burhanuddin dan Adaik Basandi Sarak" (The History of Shaikh Burhanuddin and Shariah as the Basis for Custom; 6 cassettes) by the indang troupe led by Alam Sudin. In 2009 Sinar Padang Records produced VCDs of indang entitled "Indang Tradisi Pariaman Asli" (Authentic Indang of Pariaman Tradition). The performance was carried out by troupes from Guguak Lurah Ampalu, Padang Baru Koto Buruak (Lubuk Alung), and Mangoe Batu Kalang villages, all situated in Padang Pariaman regency (Figure 3). I learnt from Pian (45 years), one of the senior performers of Koto Buruak troupe I interviewed (personal communication 29-10-2009), that Sinar Padang Records will continue to produce subsequent volumes of this series, all in VCD format.

Rabab Pesisir Selatan is the most popular genre of Minangkabau oral literature produced by West Sumatran recording companies. The rabab Pesisir Selatan singers are engaged by cassette producers more often than their comrades from any other genre. This genre employs lyrical prose using modern Minangkabau language and adds colour to humour (see note 9). Commercial recordings of rabab Pesisir Selatan have been made in cassette and VCD format. Most singers of this genre have released cassettes and VCDs, as for example Syamsuddin, Pirin Asmara, Siril Asmara, Erman, Ardiman, Aslim, Lidar Kambang, and Hasan Basri. In several recordings the male singers appear in duet with the female singers such as Nurana and Erni (Figure 4).

Syamsudin seems to have been the first singer to have released rabab Pesisir Selatan commercial recordings. After succeeded with his first recording of "Kaba Hasan Surabaya" in 1971 (5 cassettes), Syamsuddin then appeared in the recording of "Kaba Merantau ke Jambi" (The Story of Migrating to Jambi; 5 cassettes), produced by Tanama Records in 1975 (Phillips 1991: 81-82). This was followed, over the next years, by further rabab Pesisir Selatan cassettes from Tanama Records. Again with the singer Syamsudin, Tanama produced recordings of "Lamang Tanjuang Ampalu" (The Story of Roasted Sticky Rice from Tanjung Ampalu; 5 cassettes), "Carito Zamzami \& Marlaini" 25 (The Story of Zamzami and Marlaini; 4 cassettes), "Kaba Rukiah jo Malano" (The Story of Rukiah and Malano; 14 cassettes), and "Kisah Ridwan" (The Story of Ridwan; 4 cassettes). Tanama Records also released the story "Merantau ke Malaysia" (Migrating to Malaysia; 4 cassettes), "Carito Abidin \& Bainar"26 (The Story of Abidin and Bainar; 5 cassettes), and "Puti Gondoriah" (The Princess Gondoriah; 5 cassettes) with the singer named Pirin Asmara, and "Kaba Busama" (The Story of Busama; 3 cassettes and 3 VCDs) with the singer named Aslim (Figure 4).

25 For further on the transcription of these story, see Suryadi (1993a).

26 For further on the transcription and structural analysis of these recordings, see Arni (1995). 

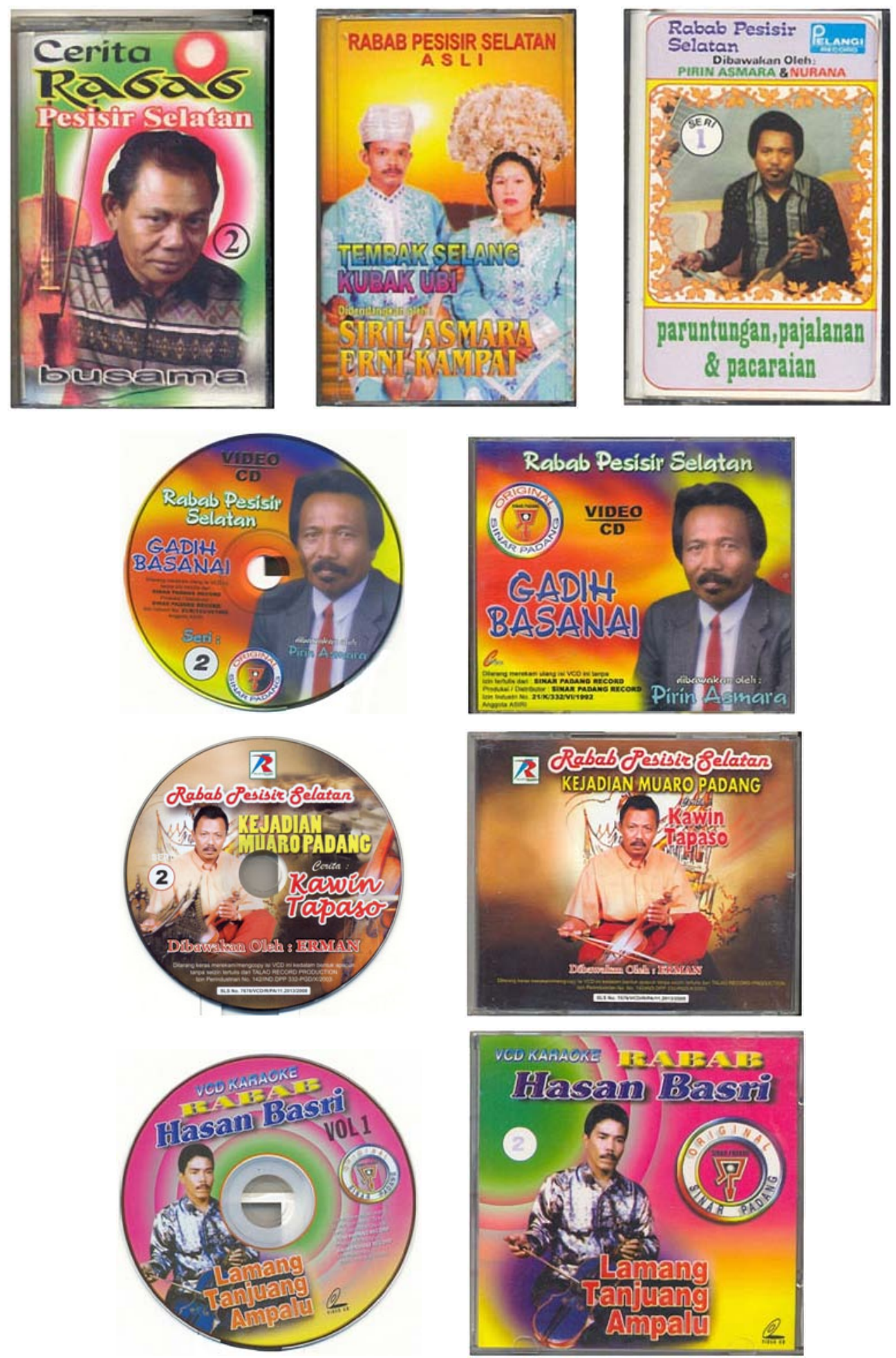

Figure 4. Rabab Pesisir Selatan cassette covers (above); rabab Pesisir Selatan VCDs and their covers (below). 
The success gained by Tanama Records in marketing commercial recordings of rabab Pesisir Selatan seems to have inspired other companies also to produce commercial cassettes and VCDs of this genre. Among them are Pelangi Records, Sinar Padang Records, and a new competitor, Talao Records. Sinar Padang is notable for released the largest number of rabab Pesisir Selatan titles in VCD, which it has been producing since the early 2000s. Thus for example, it had produced "Kaba Derita Hati Ibu" (The Story of Mother's Heart-ache; 6 VCDs), "Kaba Lamang Tanjuang Ampalu" (The Story of Roasted Sticky Rice from Tanjung Ampalu; 5 VCDs), and "Kaba Kejadian di Batipuah Padang Panjang: Abu Nasar dengan Rosni" (The Story of Occurrence in Batipuh, Padang Panjang: Abu Nasar and Rosni; 7 VCDs), sung by singer Hasan Basri, and "Kaba Gadih Basanai" (The Story of Basanai; 5 VCDs) sung by the singer Pirin Asmara (Figure 4). Sinar Padang also produced "Raun Sabalik", a version of rabab Pesisir Selatan, sung by the singers Hasan Basri and Kawat (1 VCD). Whereas Talao Records produced the VCDs of "Kaba Kejadian di Muaro Padang: Kawin Tapaso" (The Story of Incident in Muara Padang: Forced Marriage; 5 vols) sung by the singer Herman (Figure 4).

Dendang Pauah seems to have released in cassette format only, with titles such as "Kaba Seorang Bapak yang Tidak Bertanggung Jawab" (The Story of an Irresponsible Father; 3 cassettes), produced by Tanama Records (Figure 5). It was sung by the singer Harun St. Rajo Bujang and the tukang saluang (fluteplayer) Syarif Bagindo Basa. This story is nothing other than a modern version of "Kaba Urang Lubuak Sikapiang" (The Story of Lubuk Sikaping People) (see Suryadi 1993b). Another performance by Harun recorded by Tanama is "Pasan ka Rantau" (Message to Our Emigrants; 1 cassette). Tanama also released "Kaba Siti Jamilah" (The Story of Siti Jamilah; 3 cassettes), performed by Burhan (singer) and Indiak (flute-player).

Sijobang performances have also been released in commercial cassettes. Around 1974 Tanama Records produced the first commercial cassettes of sijobang (5 vols) sung by the singer Samsuwir N. (Figure 5). Some amateur recording companies in Payakumbuh area of the Lima Puluh Kota regency also released sijobang recordings in the 1980s, which were sometimes played by vendors of folk-medicines (panggaleh ubek) to attract customers (Phillips 1981: 9). However, in recent times it has been difficult to find commercial recordings of sijobang in the market. Tanama Records and other West Sumatran recording companies situated in Padang and Bukittinggi no longer produce commercial recording of this genre. ${ }^{27}$ Perhaps this due to the fact that its cassettes are seemingly consumed only locally by the Minangkabau from Payakumbuh and surroundings, as the language of sijobang's text is very coloured by the Payakumbuh dialect of the Minangkabau. Hence, sijobang is not so popular in other regions of West Sumatra because the language of its

27 Likewise the ronggeng Pasaman genre, which, according to Indra Nurdin (41 years), the warehouse manager (kepala gudang) of Tanama Records, was produced by his company in the mid 1980s. According to Indra, Tanama Records no longer (re)produces ronggeng Pasaman cassettes because of low consumers demand (personal communication 25-9-2009). For further information about ronggeng Pasaman, see Amir, Zuriati, and Anwar (2006: 129-131). 
text is not agreeable to the ears of Minangkabau language speakers outside the Payakumbuh dialect area.
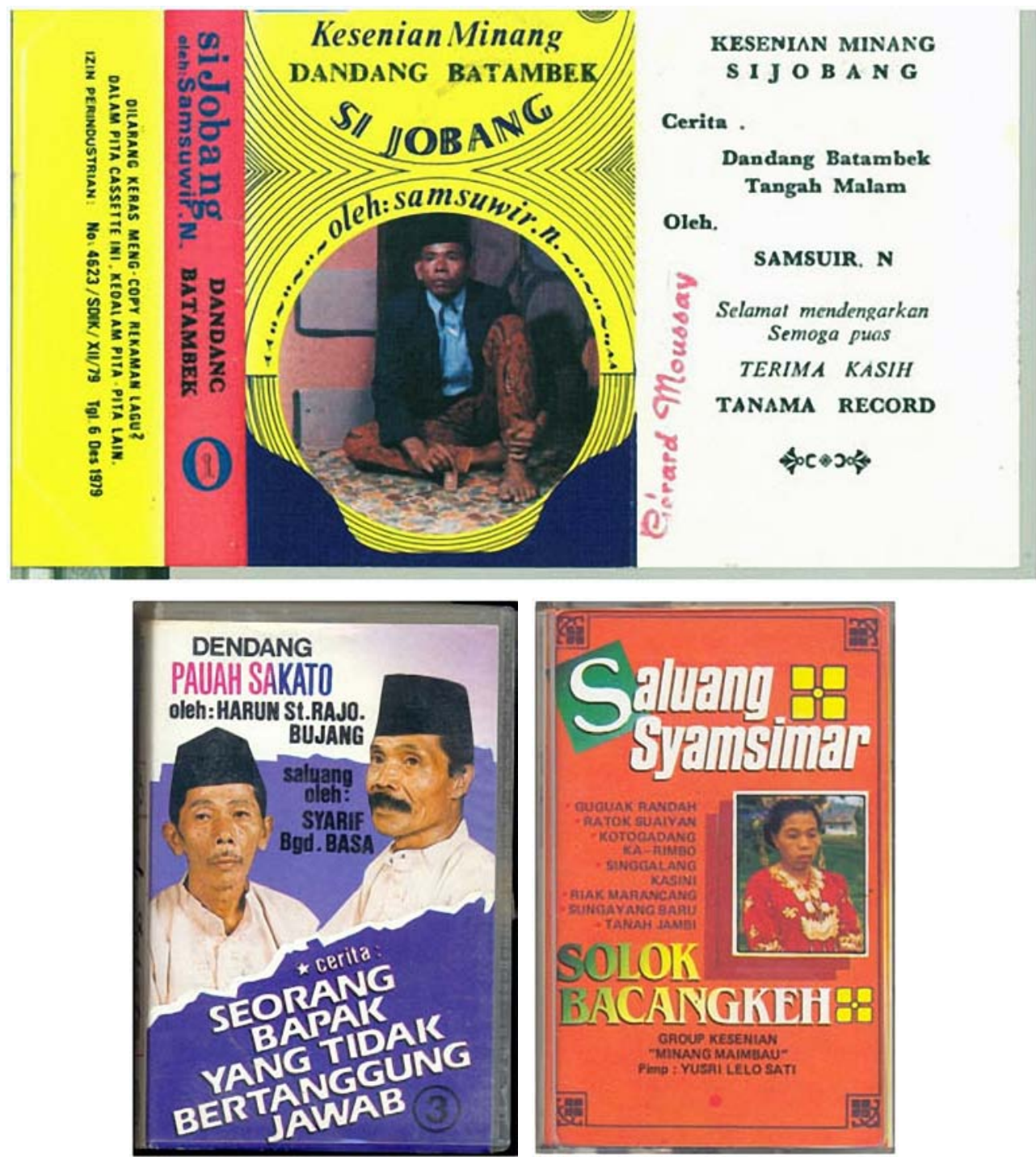

Figure 5. Sijobang cassette cover (above), dendang Pauah and saluang (bagurau) cassette covers (below); Photo sijobang cassette cover by Nigel Phillips; cassettes were initially owned by Gerard Moussay.

Saluang or bagurau, which have been recorded ever since the gramophone era, have also been released both in cassette and VCD format. They are mostly produced by Tanama Records. One example is "Solok Bacangkeh" (Solok has Cloves) by the Minang Maimbau troupe with its well known female singer, Syamsimar (Figure 5). It is called saluang klasik (classic saluang). In 2009 some producers like Minang Records and Nada Music Records in Bukittinggi produced the VCDs of this classic saluang (Figure 6). Nowadays, due to 
the influence of the West Sumatran regional recording industry, saluang is adopting new text and musical styles that incorporate elements of pop Minang. This transformation is reflected on the covers of saluang cassettes and VCDs in the new style, which is described as saluang maso kini (contemporary saluang) (Figure 7), saluang dangdut (dangdut saluang) and dendang saluang mode AseRege (chanting saluang Asereje-style) - the latter was inspired by the song melody of "Asereje" by three Spanish sisters known as "Las Ketchup" that became hit worldwide in 2002.
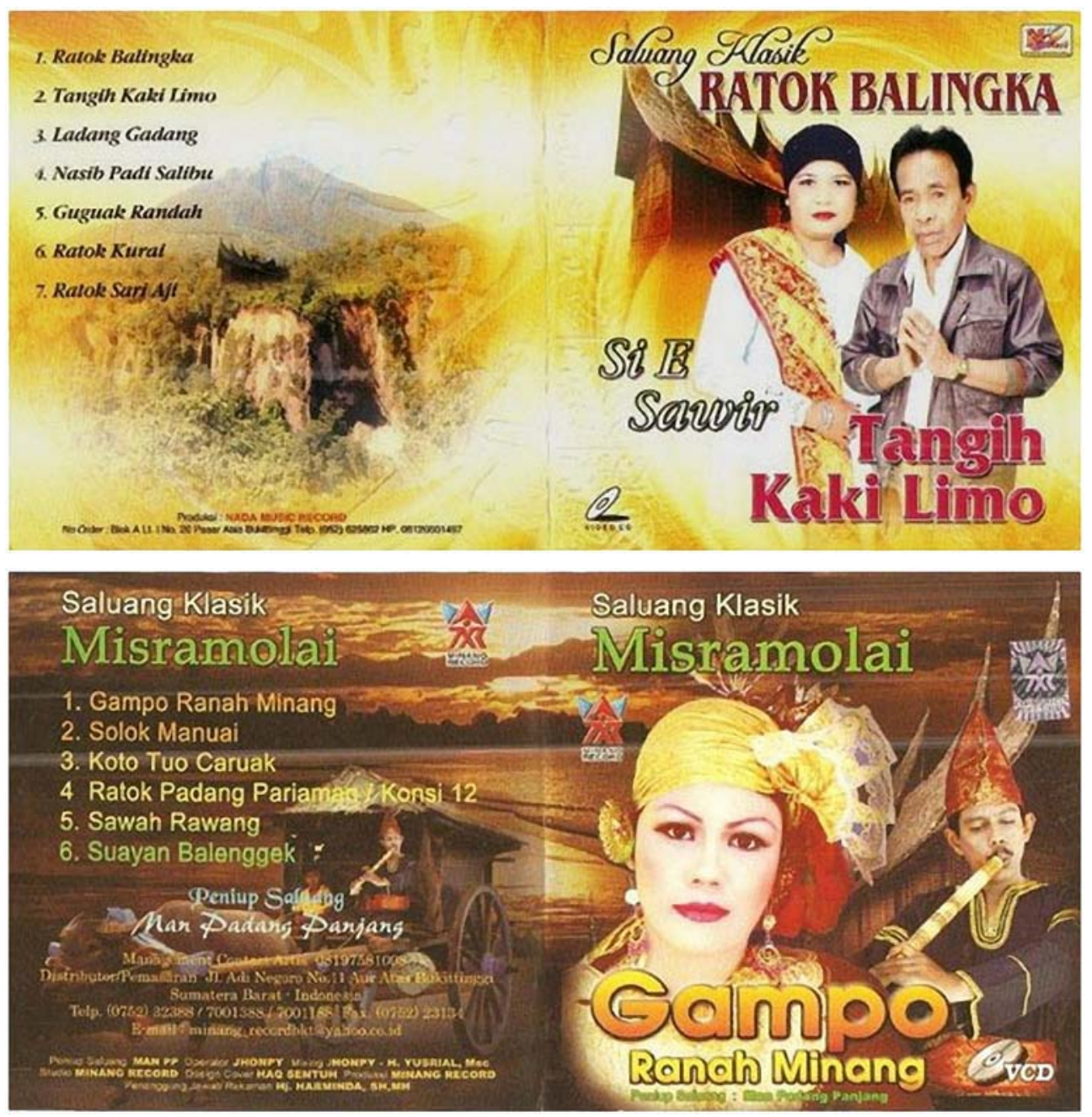

Figure 6. The VCD covers of two recent commercial recordings of classic saluang; Photos by Andiko Sutan Mancayo.

Randai recordings have also appeared on cassette and VCD. Among the randai cassettes that were produced by Tanama Records are "Kaba Salendang Dunia" (The Story of Salendang Dunia; 2 cassettes) performed by Karih Pusako troupe; "Kaba Puti Ambun Suri \& Buyuang Sarunai" (The Story of Princess Ambun Suri and Buyuang Sarunai; 2 cassettes), and "Kaba Palimo Gaga jo Reno Nilam" (The Story of Commander Gaga and Reno Nilam; 2 cassettes) 
performed by Pulai Sati troupe; "Kaba Siti Rowani" (The Story of Siti Rowani; 3 cassettes) and "Kaba Magek Manandin" (The Story of Magek Manandin; 3 cassettes) performed by the Rumah Gadang ' 83 theatre troupe ${ }^{28}$ in Jakarta. Since the 2000s randai recordings have also produced in VCD format. Thus for example, the VCD of "Kaba Bujang Denai \& Nilam Suri" (The Story of Bujang Denai and Nilam Suri) and "Kaba Rambun Pamenan" (The Story of Rambun Pamenan; 4 VCDs), both produced by Minang Records in Bukittinggi (Figure 7). Minang Record also released these recordings in cassette format. Randai VCDs enable the audience to enjoy not only the audio aspect of this Minangkabau folk theatre, but also its visual aspect.

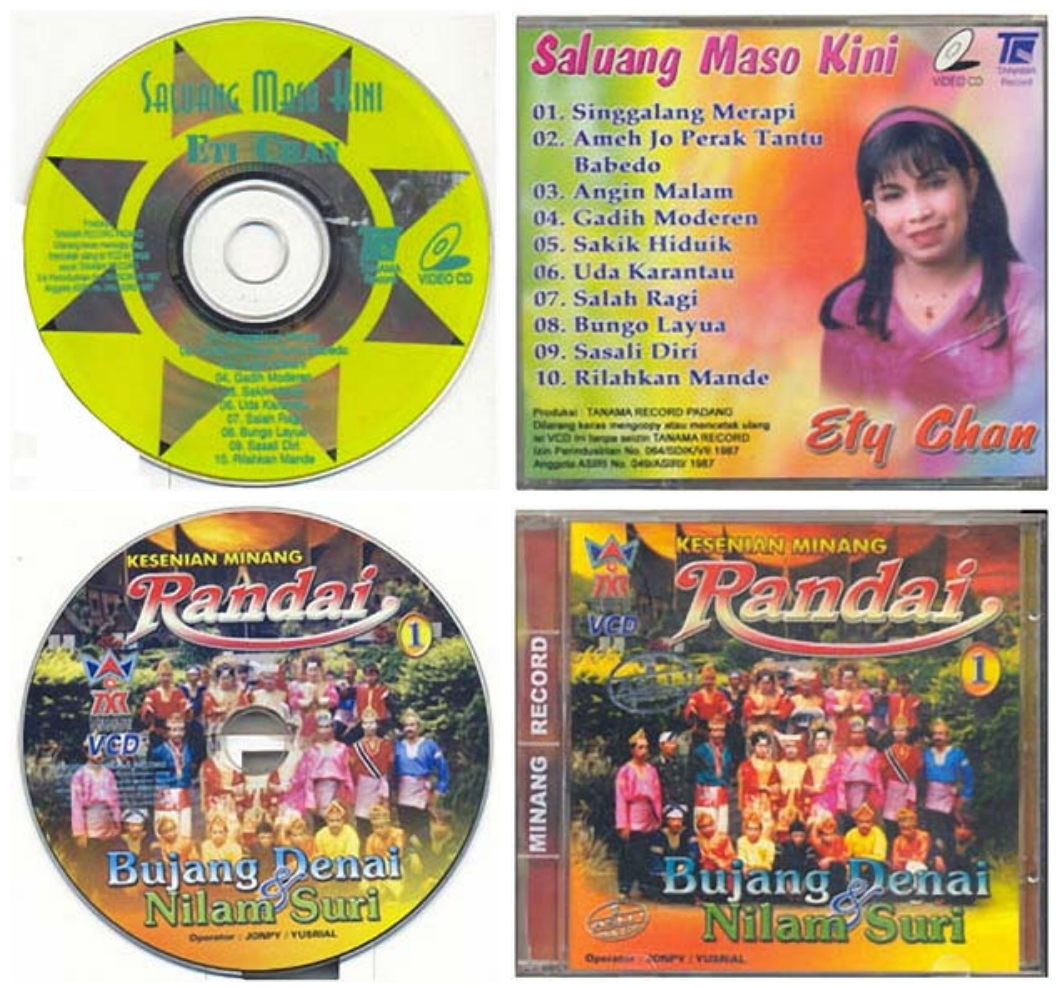

Figure 7. Modern saluang VCD and its cover (above) and randai VCD and its cover (below).

The salawat dulang commercial recordings now are available in cassette as well as VCD format, mostly produced by Tanama Records. The recordings have wide appeal in this Muslim community (Amir, Zuriati, and Anwar 2006: 53-60). Some prominent salawat dulang troupes from Tanah Datar and Agam regencies have been recorded by Tanama. Among salawat dulang cassettes released by this company are "Nabi Ibrahim dan Pengorbanan-Nya" (The Prophet Abraham and His Sacrifices) performed by Piriang Talayang troupe faces Gurun Sahara troupe (Figure 8), "Takalo Nyao Kabapulang" (When

28 For further information about this theatre troupe, see my description about mediabound genres below. 
the Soul is About to go Home) performed by Arjuna Minang troupe meets DC 8 troupe (Figure 8), "Sabalun alun baralun" (Before the Time Began) and "Mengenal Hal Tubuah Nan Salapan" (On the Eight Components of Human Body) performed by Kilek Barapi troupe faces DC 8 troupe (Figure 8). Whereas "Martabat Diri" (Self Respect; 2 VCDs) performed by Arjuna Minang troupe faces Langkisau troupe and "Nyawa dan Kulimah" (The Soul and the Confession of Faith) performed by Kilek Barapi troupe meets DC8 troupe is recorded in VCD format (Figure 8).
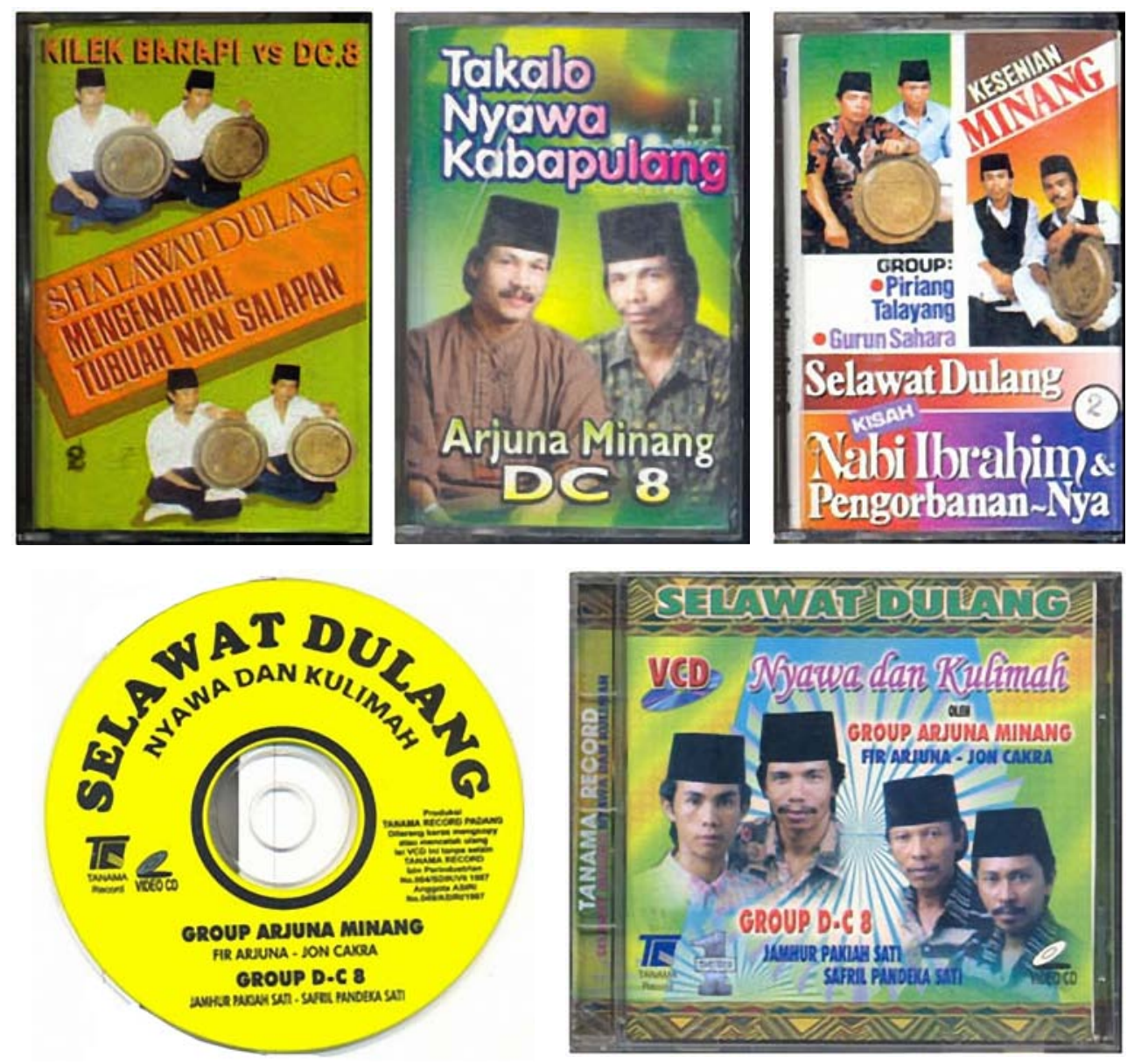

Figure 8. Salawat dulang cassette covers (above); a salawat dulang VCD and its cover (below).

The pidato adat dan pasambahan recordings seem to have been produced since the 1980s, pioneered by Yus Dt. Parpatiah, a panghulu (lineage head) from Maninjau, West Sumatra, who became as the leader of the Rumah Gadang '83 theatre troupe in Jakarta (see Suryadi 2003a: 61). Commercial recordings of this genre have appeared only in cassette format. Among Yus Dt. Parpatiah's cassettes in this genre are "Kepribadian Minang" (Minangkabau Personality; 2 cassettes), "Nasehat Perkawinan Versi Adat" (Adat Version 
on Marriage Advices; 2 cassettes), "Baringin Bonsai: Krisis Kepemimpinan Niniak-Mamak di Gerbang Era Globalisasi" (The Bonsai Banyan: A Crisis of Village Leadership in the Transition to Globalization; 2 cassettes), "Konsultasi Adat Minangkabau" (Consultation on Minangkabau Custom; 2 cassettes), and "Pitaruah Ayah untuak Calon Panghulu" (Father's Advice for a Candidate Lineage Head; 2 cassettes) (Figure 9).
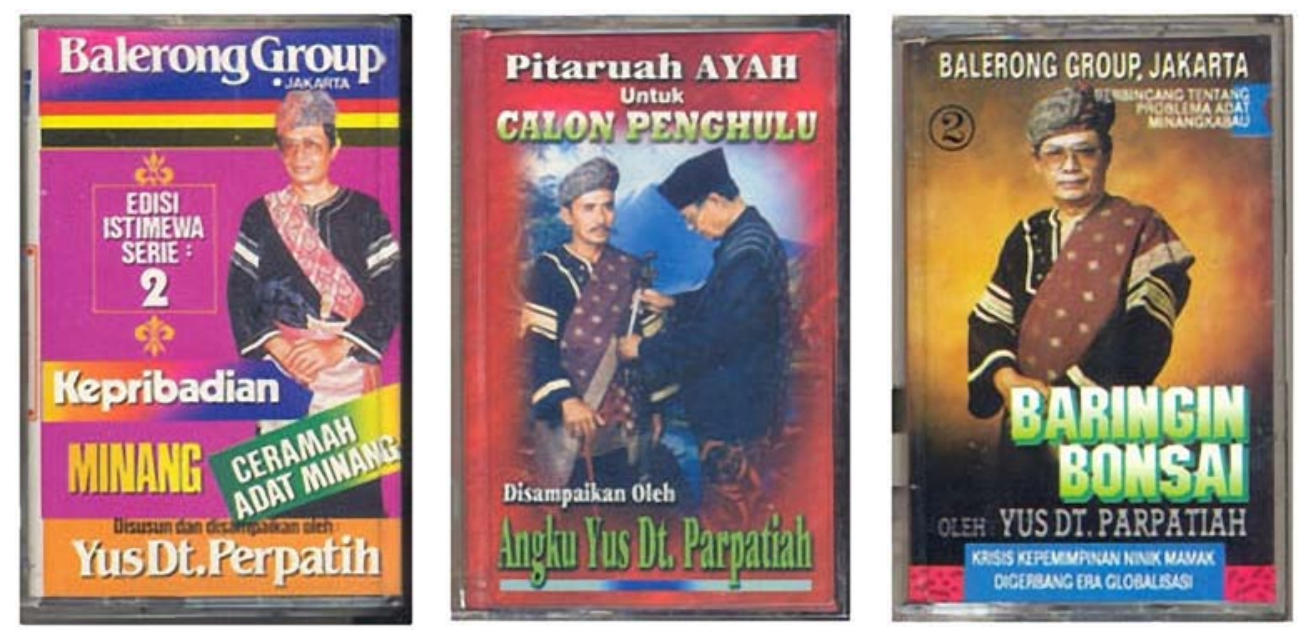

Figure 9. The cassette covers of Minangkabau speech making narrated by Yus Dt. Parpatiah.

\section{THE ADVENT OF MEDIA-BOUND GENRES}

Media cultures are shaped by the process of cultural mediation, which formed what may be called media-bound genres. These are genres that are heavily dependent upon the media and have no original counterparts in public performances. In the case of Minangkabau verbal art, there are indeed media-bound genres that exist only in media such as cassette, VCD, radio, and television. One newly created Minangkabau verbal art genre which can be categorized as a media-bound genre is drama Minang moderen (modern Minangkabau drama). ${ }^{29}$ This genre was created in the 1980s by two Minangkabau theatrical-troupes established by some Minangkabau emigrants (perantau) in Jakarta. They are Balerong Group (balerong means "royal audience hall") established by Yus Dt. Parpatiah ${ }^{30}$ in 1980 and Teater Rumah Gadang ' 83 established by Yus Pilihan. The cassettes were produced by recording companies such as Globe Records, Tanama Records, and Sinar Padang Records. Some of them are still reissued today but they have never been released in VCD format. Among the titles of such cassette dramas are "Diseso Bayang" (Tormented by the [Beloved] Shadow), "Kamari Bedo" (All Wrong),

29 Another Minangkabau media-bound genre is Minangkabau children's pop music which is not further discussed here because it can be subsumed in the genre of pop Minang. On the Minangkabau children's pop music, see Suryadi 2003 b.

30 As mentioned above, Yus Datuak Parpatiah also made commercial recordings of pidato adat dan pasambahan ceremonial speech-making, produced by Tanama Records. 
“Di Simpang Duo” (In a Dilemma), “Kasiah Tak Sampai” (Unrequited Love), "Rajo Angek Bacakak jo Turih" (Rajo Angek Clashes with Tourists), "Ratok Mak Enggi" (Lament of Mak Enggi), "Rapek Mancik" (Mousse Meeting), "Nurmala" (the name of female protagonist in this story), and "Puber Kaduo" (Second Puberty) (Figure 10).
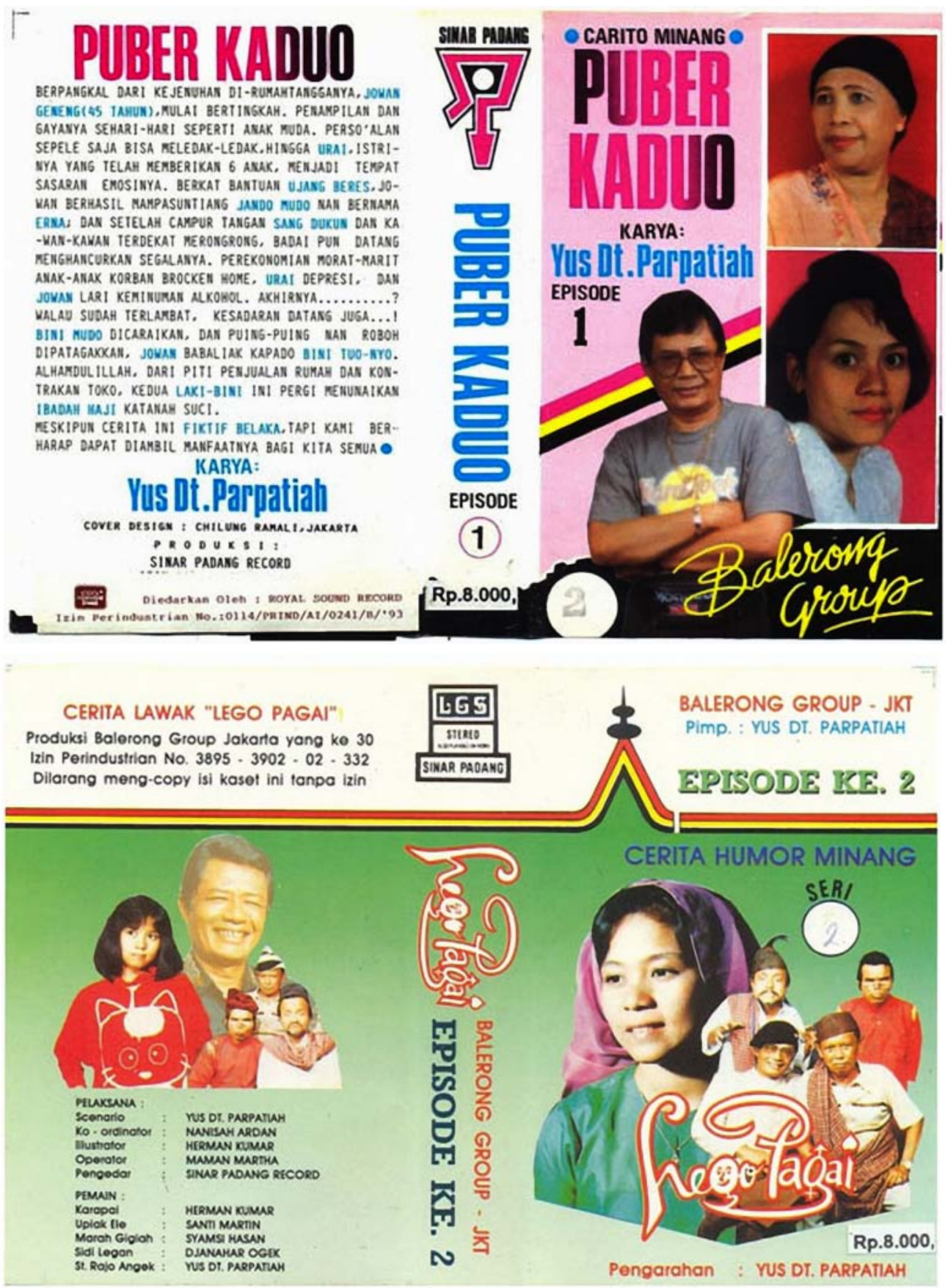

Figure 10. Modern Minangkabau drama cassette covers. 
These Modern Minangkabau dramas are performed by group of five to ten male and female actors in a radio format: the actors deliver the speeches of their roles as if they were acting a play, yet the exclusively aural character of the drama performance obligates them to rely heavily on asides to the audience about the imagined scene of the action and to utilize many sound effects. Humour and jokes add flavour to the stories. Strongly orally in its character, the Modern Minangkabau drama is a combination of music and sung and spoken dialogue. Partly in Indonesian and mostly in Minangkabau language (colloquial and formal literary dialect), the stories progress via a combination of Indonesian (sometimes Jakarta-dialect), conventional village Minangkabau, ritual oratory, Minangkabau pop songs with mourning dirges, and Minangkabau traditional music. The cassette covers are made from engravings or photographic plates showing a carefully posed scene of drama troupe actors in traditional and modern costumes (depend on their roles in the story). The dramas are spread over sets of two and four standard 60-minute cassettes.

Reflecting the perceptions of Minangkabau emigrants toward the social changes occurred in their homeland and the cultural changes among the Minangkabau generations born in rantau (Rosa 1990), the themes of the stories in Modern Minangkabau dramas focus on modern Minangkabau family affairs: choice of marriage partners; inheritance disputes; the problems of living in rantau; the dilemmas and attractions of marrying with nonMinangkabau women; mamak (mother's brother) - kemenakan (nephew) ties; loyalty to custom; and cultural decay in the home village (kampung halaman). Some other stories get inspiration from local legends or Minangkabau history in the colonial era.

These modern Minangkabau cassette dramas are just one example of how ethnic cultures are represented and revitalized making use of modern media technology. Such revitalization involves the creation of new genres, predominantly by mixing pre-existing genres from both inside and outside the culture. Cassette culture enables cross-regional as well as global artistic influences and dialogic exchanges to emerge among the regional artists. The advent of a media-bound genre like modern Minangkabau drama is also an example of how media technology has motivated and inspired cultural experiment and (re)presentation. As occurred in other provinces, the West Sumatran regional recording industry has accelerated the flow of ideas concerning local culture through the mass media. With the advent of the cassette industry, Minangkabau cultural practitioners are inspired to develop innovation and experimentation in the cultural field. The Minangkabau media bound-genre such as the modern Minangkabau drama is a manifestation of such innovation and experimentation.

\section{PRODUCTION: MAKING CASSETTES AND VCDS}

With a keen business spirit, Minangkabau producers have competed actively with each other in producing commercial recordings of Minangkabau oral 
literature. Due to this competition among recording companies, many traditional performers of Minangkabau oral literature genres have had the opportunity to be released on commercial cassettes and VCDs. Usually a producer is not interested in contracting with a storyteller who has recorded with another producer. So for example, the singers of rabab Pariaman Amir Hosen and Aly Umar who recorded with Tanama Records have never been approached by Sinar Padang Records. Conversely, the singer of rabab Pesisir Selatan, Hasan Basri, who had been recorded by Sinar Padang, was never contracted by Tanama. This keen competition among the producers has given opportunities for many more Minangkabau storytellers to engage with recording companies.

Recordings of Minangkabau oral literature, whether in cassette or VCD format, and whether containing kaba or non-kaba material, often come out in multi-volume set. The recording of "Kaba Nan Gombang Patuanan \& Sutan Pangaduan" of rabab Pariaman, for example, takes twenty 60-minutes cassettes. As far as I know, this is the longest commercial recordings of kaba ever produced by a West Sumatran recording company, while "Kaba Rukiah jo Malano" of rabab Pesisir Selatan produced by Tanama Records turns over 14 cassettes. Many other kaba recordings take fewer cassettes: 4 to 6 . The kaba VCDs also run over several volumes, covering up to 7 VCDs. The non-kaba recordings, such as "Raun Sabalik" of rabab Pariaman performed by Aly Umar, or the version "Jalan Kuliliang Bilang Nagari" performed by Amir Hosen, take one or two cassettes. The media-bound genres of modern Minangkabau cassette drama also appear in multi-volume sets.
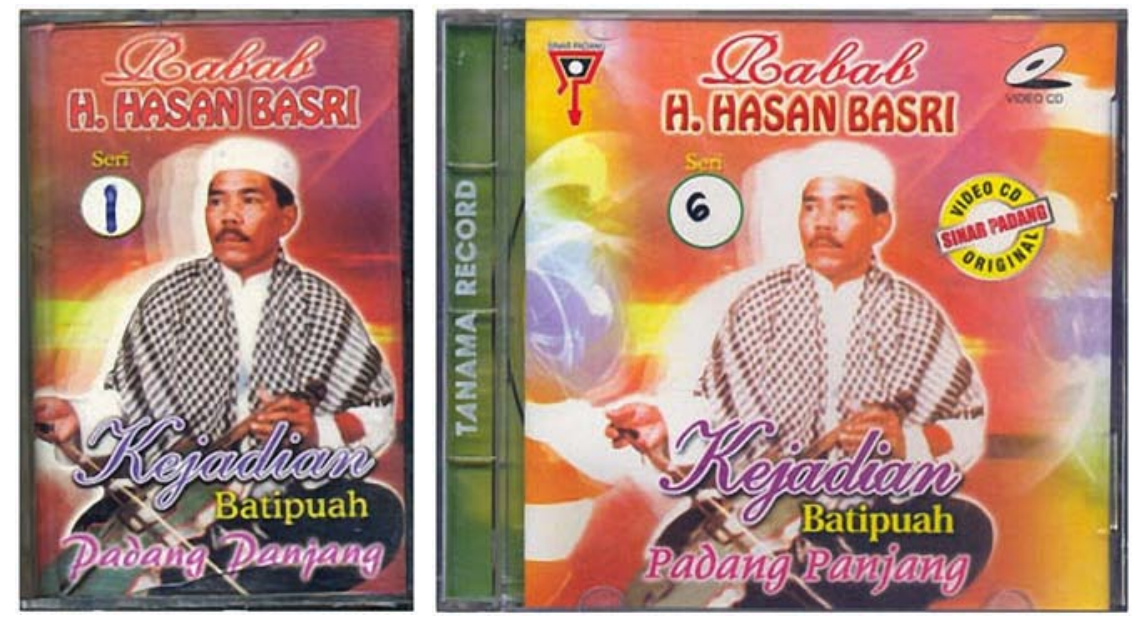

Figure 11. The "Kaba Kejadian di Batipuah Padang Panjang" cassette cover (left) and VCD cover (right) of rabab Pesisir Selatan produced by Sinar Padang Records.

Some recordings of Minangkabau oral literature are released on both cassette and VCD (Figure 11). They are released first in cassette format, and then, if the market demand is high, the producers will re-release the recordings in VCD format. This process is evident on many Minangkabau oral literature VCD 
covers, which read: Miliki juga kasetnya!!! (Own its cassettes too!!!), indicating that the VCDs have their own cassette versions. On the contrary, cassettes never urge Miliki juga VCDnya! (Own its VCD too!). It is thus evident that the cassette versions of the recordings were produced earlier than their VCD counterparts. In such cases, the producers apparently use the same master recordings for both the cassette and VCD version.

Though the producers and West Sumatran recording industry practitioners whom I interviewed would not divulge exactly how many copies of each recording have been made, two of them, Agusli Taher (59 years), the owner of Pitunang Records and the former executive board of Asosiasi Industri Rekaman Indonesia (abbreviated ASIRINDO, Indonesian Recording Industry Association) West Sumatra branch, and Indra Nurdin (41 years), the warehouse manager (kepala gudang) of Tanama Records, told me that each recording of Minangkabau oral genres or pop Minang albums was produced in an edition of 2000 copies of cassettes or VCDs respectively. However, it is difficult to obtain true statistics on the production numbers of West Sumatran recording companies since many producers seem reluctant to give information on how many recordings their companies had made and sold. It may be that they do not want outsiders to realize the significant profits they have made.

In the West Sumatran recording industry, the performing artists of pop Minang and the storytellers of Minangkabau traditional oral literature have weak bargaining positions vis à vis the producers. The latter have the power to determine the performers' contracts and to control the products. As has occurred in other regions (compare Weintraub 2004: 170 on process production of Sundanese wayang golek commercial cassettes), the performers have been excluded from decisions relating to aspects of production, including editing. The producers also have unlimited rights to reproduce the master recordings. This is due to the customarily applied contract system called jua putuih (outright sale) or jua master-master (master recording sale), which means that the producers buy the master recordings in perpetuity, and can reproduce them as they see fit. Usually the storytellers of Minangkabau oral literature do not receive additional royalties or remunerations from their reproduced cassettes or VCDs. Dates of production date are not usually noted on cassette and VCD covers, so it is difficult to calculate how many times a master recording has been reproduced by a producer. Thus the jua putuih contract system is exceptionally beneficial for the producers because they can reproduce unlimited numbers of copies from the master recordings they hold.

Most master recordings of Minangkabau oral literature genres in cassette format have been made in studios. The established producers such as Tanama Records, Sinar Padang Records, and Talao Records have their own recording studios, which are sometimes rented by other producers who do not own a recording studio or by producers of regional pop recordings from 
neighbouring provinces like Jambi and Riau. ${ }^{31}$ When the master recordings are produced in a studio setting, it means that the performances are carried out without the participatory audience which would be present in public performances, in which audience reactions "affects the nature and purpose of performances of oral poetry in various ways" and "often have an effect on the form and delivery of a poem" (Finnegan 1977: 231).

Likewise the master recordings for Minangkabau oral literature genres in VCDs format are also made in studio, while the video clips are made outside the studio. In an interview with Pian (45 years), a senior performer in the indang troupe from Koto Buruak, Lubuak Aluang who was involved in the production of "Indang Tradisi Pariaman Asli" VCDs (3 volumes) released by Sinar Padang Records in 2009 (Figure 3), he explained that the performances for the master recordings of the VCDs were first recorded in the studio of Sinar Padang Records in Padang. After that the troupes performed again in public in some locations in Pariaman, by day and night, to shoot video clips which were then integrated into the VCDs. During the public performances, the master recording was played in order to keep the performances synchronized. This technique is also used in making VCDs at the national level in Indonesia (see Wallach 2008).

Duplication of copies from the master recordings, both for cassettes and VCDs is carried out in Jakarta. According to the owner of Pitunang Records, Agusli Taher (59 years), who his name mentioned above, cassette producers are unwilling to establish a recording factory in West Sumatra because of the high cost involved, and the likelihood that it would not be profitable if relies only on local consumers (personal communication 11-01-2010). For these reasons of cost, the duplication process of the master recordings is still carried out in Jakarta.

\section{THE EFFECT OF RECORDING TO THE BODY OF ORAL TEXTS}

My investigation on the narrative of $k a b a$ in commercial recordings shows that the storytellers take the medium into account when they compose texts for commercial recordings. This means that there are some particular characteristics in the texts of oral literature genres performed for commercial recordings. Thus for example, the particular lines and some formulaic expressions found in the recorded texts suggest that the storytellers are aware of the limited space available on media like cassette and VCD. Consequently, this influences some features of the recorded texts, which differ from their counterparts composed in public performances. When watching the indang VCDs produced by Sinar Padang Records mentioned above, I noticed some couplets in which the performers say that they could not talk at length because time does not allow (dek wakatu indak maizinan), indicating that a consciousness

31 For example, Riau's pop Kampar commercial cassettes, which are well-known as ocu songs (ocu is a greeting word for one's older brother in the Malay of Kampar dialect) and Jambi's pop Kerinci, are produced by West Sumatran Recording companies such as Minang Records and Tanama Records (see Suryadi 2005: 146). 
of the limited space on a VCD inclines the performers to save time. In other couplets the performers remind the audience that they just performing for fun in the studio, implying that the performance they are making for the recording is not a competitive tussle as it might be in a public performance.

\section{Mako dek tupai balun baambiak}

Buah jo tampuak carai alun patuik

Kok diresek-resek buah nan masak

Urang punyo kabun kok

marameh paruik

Mukadimahe ndak dipapanjang

Cuma ka panonton sajo nak dagang sabuik

Nak jaleh bana dek urang banyak

Di Sinar Padang kami main bagaluik ${ }^{32}$
The reason why squirrels have not taken the crop

Is that it's too soon for the fruit to part from the calyx

If the ripe fruits are squeezed

The owner of the garden might be frightened

The introduction will not go on any longer

I just want to say to the audience

In order to make it clear to the public In Sinar Padang Records' [studio] we perform for the fun of it

Actually, the oral literary texts recorded on cassette or VCD tend to be condensed as, for example, has been shows by Nigel Phillips who compared a rabab Pesisir Selatan text "The Story of Migrating to Jambi" performed at a wedding near Padang and its commercial cassette version, both with the same plot and sung by the singer Syamsudin (Phillips 1991, 1992). The wedding performance took about 6 hours to sing, that is about one hour and a quarter longer than the studio recording. ${ }^{33}$ " [T] performance was, on the whole, somewhat less condensed than that of the studio performance" (Phillips 1992: 67). Syamsudin told Phillips that the producers sometimes remind the performers to condense the text. Phillips also noticed a lack of parallelism in Syamsudin's stories on cassettes.

When asked about the lack of parallelism in his stories, Syamsudin said that he purposely left out repetitions and unnecessary phrases and tried to speed up his stories because the recording company wanted him to use fewer cassettes per story. This is presumably from a wish to save on fees [...] and to make the stories more attractive to buyers (Phillips 1991: 84).

Nevertheless, it seems that not all recording companies apply this policy, as

32 “Indang Tradisi Pariaman Asli" (Sinar Padang Records 2009, 3 VCDs): VCD no. 3, angle (sandiang) 3 .

33 It reminds me to Garrett Kam's study on the influence of commercial cassettes on the Javanese classical dances (Kam 1987). He also found that the text of Javanese classical dances exist in commercial recordings are shorter that their counterparts exist in public performances. 
indicated the recording "Kaba Nan Gombang Patuanan \& Sutan Pangaduan" of rabab Pariaman produced by Tanama Records which takes 20 cassettes, as mentioned above. However, we can assume that the text of this kaba performed in the recording studio is not necessary the same as its counterparts presented in public performances. A dictum in the theory of oral literature says that circumstances (including audience response) influence the oral form (Lord 2003: 14). There is a difference between oral literature performances conducted in front of a listening public and those carried out in the recording studios for commercial purposes. In a public performance, the singer interacts with a participatory audience: they make comments, whistle, and clap in response to the singers. ${ }^{34}$ This situation is hardly ever experienced by the singers of oral literature recorded in the recording studios. Yet spontaneity and audience interaction is an intrinsic part of oral text performance.

In the case of literary poem there is a gap in time between composition and reading or performance; in the case of oral poem this gap does not exist, because composition and performance are two aspects of the same moment. Hence, the question "when would such and such an oral poem be performed?" has no meaning; the question should be "when was the oral poem performed?" An oral poem is not composed for but in performance. [...] We must eliminate from the word "performer" any notion that he is one who merely reproduced what someone else or even he himself has composed. Our oral poet is composer. Our singer of tales is a composer of tales. Singer, performer, composer, and poet are one under different aspects but at the same time. Singing, performing, composing are facets of the same act (Lord 2003: 13, emphasis in the original).

As every performance is in some respects a new creation for the singer, every oral literature performance results in new text. Consequently, performances conducted in the recording studios result in texts which show specific adaptations by the singer to the circumstances studio recording, which usually lack a participatory audience. The singers' awareness of these circumstances is sometimes made explicit. For example, the singer Amir Hosen in "Kaba Nan Gombang Patuanan \& Sutan Pangaduan" of rabab Pariaman uses formulaic verse elements (pantun) to suggest that his text was being performed for a commercial recording. He says (my emphasis):

Ujuang tali pangabek paga

Putuih bajelo masuak balai Jelo-bajelo ka kadaian Ujuang nyanyi jatuah ka kaba
The end of the string for binding the fence

Broken, it trails into the market Trailing and trailing into the shops The end of the string falls into the

34 Even in performances of some Minangkabau oral literature genres we found fanatic audience (penonton fanatik). Thus for example, in indang and dendang Pauah performances they are called sipatuang sirah (literally means "red dragonfly"). Associated with the dragonfly character which brings about appeal for circumstance, sipatuang sirah, who have close relationship with the performers, have the duty of provoking the spectators to always enthusiastic with the singer(s) during the performance take places by giving comment, clapping, and sound of sizzling frequently (see Suryadi 1993b: 21-22, 1994: 231). 


\author{
story \\ Sakarang kini kito mulai \\ Now we are beginning it \\ Disambuang [di] kaset nan kalapan ${ }^{35}$ It is continued on cassette number eight
}

In the couplet quoted above Amir Hosen announces that he continues the singing on cassette number eight. Whenever he moves to the next cassette, he uses this formulaic expression, changing the end rhyme of line three and line six. Such a media-specific formulaic verse is also found in the indang VCDs, as indicated in the quotation below (my emphasis).

Jadi sahinggo itu dulu

Nan lain lo lai carito nak diulangi

Balambek-lambek daulu ka kami sabuik

Ka Sinar Padang mintak tarimo kasih

Sungguah bapisah kita di hari siang

Kaset kaampek nantik samo dinanti ${ }^{36}$ We'll wait together for cassette number 4
That is enough for now

I shall repeat different story

We will recount it slowly at first

Thanks to Sinar Padang [Records]

Though we are apart in the daytime

In sum, it can be said that the engagement of oral literature genres with new media like cassettes and VCDs affects their texts. The texts of studio performances tend to be condensed, due to the presence of less parallelism, fewer pairs of synonyms, or fewer long vocative phrases, though genre-specific formulaic elements are retained, an indication that the texts are mediated texts.

\title{
AUTHENTICITY AND MODERNITY
}

Interestingly, on indang cassette and VCD covers, the words Pariaman asli (genuine Pariaman) always appear (Figure 3). This distinguishes it from a genre with the same name from Solok regency, which differs in text and performance (see Amir, Zuriati, and Anwar 2006: 84-88). But further it makes the claim that the genre recorded in the cassettes and VCDs is the traditional version of Pariaman indang, which is performed by male performers only, and not the new modified modern version (indang moderen), performed by male and female performers which is usually put on as a cultural attraction for tourism, and which has generated some criticism by some cultural observers in West Sumatra. ${ }^{37}$ Conversely, as mentioned above, the rabab Pesisir Selatan commercial cassettes sung by Syamsudin, are labelled gaya baru (new style) (Phillips 1991: 81), suggesting the storytellers' attitude to modernity. By contrast, another cassette cover describes Siril Asmara and Erni's performance (Figure 4) as rabab Pesisir Selatan asli (Genuine rabab Pesisir Selatan) and both performers wear Minangkabau traditional fashion. From a semiotic point of

35 "Nan Gobang Patuanan \& Sutan Pangaduan" (Tanama Records 1996, 20 cassettes): cassette no. 8 .

36 "Indang Tradisi Pariaman Asli" (Sinar Padang Records 2009, 3 VCDs): VCD no. 3, angle (sandiang) 3 .

37 One among them is the cultural observer and stage actor Wisran Hadi, who often criticizes the exploitation of Minangkabau art for tourism in his weekly cultural columns in the local daily Padang Ekspres published in Padang. 
view, the visual elements embodied in the body of commercial recordings, such as titles, clips, and cover illustrations, can be seen as signs or symbols which embrace cultural meanings. Thus the auditory and the visual elements of a cassette or VCD form a complex cultural package of various expressive and commercial media. ${ }^{38}$

Observing the cover images of cassette and VCD covers of Minangkabau oral literature genres, we can categorize them into two types: those expressing modernity and, alternatively, those representing authenticity. The rabab Pesisir Selatan singers Pirin Asmara and Hasan Basri, for example, appear in clear and well-lit photographs, fashionably dressed. Thus for example, in his VCD entitled "Gadih Basanai" (Figure 4), Pirin is in a Western style working suit with necktie and jacket. His depiction in this novel modern fashion on the VCD cover conveys the impression that rabab Pesisir Selatan is not a Minangkabau traditional verbal art genre. Hasan Basri in his VCDs also appears in modern fashion wearing a costly batik (Figure 4), western-style shirt, or in the hajj fashion (Figure 11). By contrast, the performers of other genres such as rabab Pariaman, salawat dulang, and sijobang, appear in traditional garb on their commercial cassettes covers, as can be seen in Figures 2, 5, 6, 7, 8, and 9. The images of modernity on the one hand and of authenticity on the other hand, also emerge in the VCD clips accompanying the performances of Minangkabau oral literature.

As physical embodiments of the regional oral literature and music culture, the images on cassette covers - their printed words as well as their pictorial representation - and the video clips are crucial sites which reflect regional music and the traditional verbal art practitioner's encounter with the contemporary world. Regional cultural changes, manifested in the tension between modernity and tradition, are among other things betokened in the printed, pictorial and visual dimensions of Minangkabau verbal art cassettes and VCDs. The Minangkabau oral literature cassettes and VCDs themselves are cultural artefacts encoded with meanings. They are popular phenomena in which Minangkabau ethnicity is evoked and questions on Minang-ness, authenticity and globalization are contemplated.

\section{THE NEW ALTERNATIVES OF RECEPTION}

Needless to say, the engagement of genres of Minangkabau oral literature with electronic communication has, to a certain extent, opened up new ways of reception for them beside the traditional pattern of public performance at traditional festivities in Minangkabau villages. The competition to make commercial recordings of Minangkabau oral literature genres in cassette and VCD format has provided Minangkabau people, especially the perantau,

38 In the context of pop music, Mark Slobin has mentioned (1982: 166) that the auditory and the visual elements "are combined into a single physical embodiment of the music culture". Wong (1995: 45) furthermore said that "depending on the identity and background of the viewer, the cassette's [and VCDs] visual signs and symbols will enhance the auditory sounds and symbols of music itself." 
with a new way to appreciate the genres far from their land of origin, West Sumatra.

Some cassette retailers whom I interviewed in Padang, Pariaman, and Bukittinggi said that commercial cassettes and VCDs of Minangkabau oral literature were often bought by the Minangkabau emigrants. As we know, the Minangkabau people have a tradition of voluntary migration which is called merantau (literally "to out-migrate") (Naim 1979). It is estimated that more than half of the total of 6 million Minangkabau people now live outside West Sumatra. Their places of residence are concentrated in many towns throughout Indonesia as well as in neighbouring Malaysia and Brunei Darussalam. So, the products of West Sumatran recording companies are distributed both in the West Sumatran homeland and in the rantau as well (Barendregt 2002; Suryadi 2007b). The leading producers Tanama Records and Sinar Padang Records, for example, have established their own supplier shops in Glodok Plaza, Jakarta, in order to develop new expanding markets of potential consumers. There retailers in Java and other islands in eastern Indonesia can order Minangkabau commercial cassettes and VCDs.

So, for contemporary Minangkabau society, public performances in the West Sumatran homeland are no longer the only way of enjoying and appreciating their oral literature. Thanks to the electronically-mediated Minangkabau oral literature genres available on commercial cassettes and VCDs, Minangkabau emigrants and those who live in West Sumatra are now able to appreciate their own traditional verbal art privately. I even saw these kinds of recordings marketed in neighbouring Malaysia, where around 2.5 million people of Minangkabau descent live. ${ }^{39}$ Nevertheless, it seems that Minangkabau emigrants are not fully satisfied by consuming only the commercial recordings of Minangkabau oral genres. Recently Minangkabau emigrants invited some storytellers of Minangkabau oral literature to conduct performances in the rantau. Thus for example, some saluang and rabab Pesisir Selatan singers have often been invited by the Minangkabau emigrants living in Denpasar, Jakarta, Bogor, Bandung, Medan, Palembang, and Batam. By coming together to enjoy such performances in the rantau, the Minangkabau emigrants' yearning for their home land may be tempered. This development suggests that the mediation of oral literature genres does not threaten their live counterparts. Though cassettes and VCDs have created a new appreciating public among people, especially in urban areas of the rantau, apparently they still incline them to appreciate Minangkabau oral literature performances in public settings.

\section{CONCLUDING REMARKS}

The vast spread of the electronic media in Indonesia and the increase of its influence, to a certain extent, have transformed the country's ethnic cultures.

39 See the headline of Padang Ekspres daily entitled "Potensi perantau Minang di Malaysia. Membangun Kampung Halaman dari Potensi Rantau" (28 February 2006). 
Oral literature genres are no longer associated with the primary orality of rural society with limited literacy. Nowadays, after decades of print culture influence on Minangkabau oral literature, the Minangkabau storytellers, enticed by the West Sumatran regional recording industry, have become involved in modern electronic communication. Focusing on this occurrence in the Minangkabau cultural context in West Sumatra, this paper has shown how the mediation of Minangkabau oral literature has been stimulated by the development of West Sumatran regional recording industry. Historically commercial recordings of Minangkabau traditional verbal art were first produced in the "talking machine" era, but they became a significant phenomenon in 1980s when cassettes, and then VCDs, became widely used in Indonesia. As the West Sumatran regional recording industry has gained prominence in Sumatra, it has raised the production of commercial recordings of Minangkabau oral literature genres.

The production of commercial cassettes and VCDs of Minangkabau oral literature has had an impact on Minangkabau oral literature genres textually. Some genres, such as bagurau and rabab Pesisir Selatan, show innovations in the language diction of their texts and performance style. But other genres still maintain their traditional form. The electronic mediation has also given rise to media-bound genres, such as Minangkabau modern drama. The engagement of Minangkabau oral literature with modern electronic communication has, to a certain extent, also changed distribution, appreciation, and transmission patterns. Through commercial cassettes and VCDs, the auditory and visual dimensions of Minangkabau oral literature could now be enjoyed further away from their point of origin. Culturally, the oral literature commercial cassettes and VCDs, such as those from Minangkabau, can facilitate an emotional bridge between the emigrants and their homeland. Though connected through new electronic media with dispersed virtual audiences and regional cultural flows, the performance activities of such genres still emphasize local, grassroots identity and community, both in the homeland and in the rantau.

Analysis of the visual aspects of the physical packaging of cassettes and VCDs indicates that the mediation of Minangkabau oral literature has engaged with the dialogue on modernity and authenticity in Minangkabau society. It involves expressions local and global and overlapping understandings of "community" among the Minangkabau people. In this respect, it can be said that the electronic mass media, particularly cassettes and VCDs, contributes to the revitalization and redefining of regional cultural identity in contemporary Indonesia. In regional context, it reaffirms local sensitivity, which goes with the euphoria of regional autonomy in the contemporary Indonesian political sphere. Considering this, I must say that it is not by chance that this development coincides with what David Birch, Tony Schirato, and Sanjay Srivastava have mentioned (2001: 162) as "ethnic tension", which can be found throughout Asian region, and constitutes the most serious threat to its political stability and national sovereignty. 


\section{REFERENCES}

NEWSPAPERS/PERIODICALS

Padang Ekspres (2006)

Sinar Sumatra $(1916,1939)$

Soenting Melajoe (1921)

Sumatra-Courant (1898)

\section{CASSETTES/ VCDS}

Rabab Pariaman: "Kaba Nan Gombang Patuanan \& Sutan Pangaduan" (Tanama Records, 20 cassettes, ?1982).

Indang: "Indang Tradisi Pariaman Asli" (Sinar Padang Records, 3 VCDs, 2009).

INTERNET SITES

http://www.folkways.si.edu/projects_initiatives/indonesian/liner_notes/ volume06.html (accessed 5-3-2008).

\section{BIBLIOGRAPHY}

Amir, Adriyetti. 1996. "Salawat dulang; Sastra berangka yang dihapalkan", Warta ATL No. 2 (Juli): 5-24.

Amir, Adriyetti; Zuriati, and Khairil Anwar. 2006. Pemetaan sastra lisan Minangkabau. Padang: Andalas University Press.

Arni, Gusti. 1995. “Rabab Pasisia; Kaba Abidin dan Bainar; Sastra Minangkabau: analisis struktur". BA thesis, Universitas Indonesia.

Bagindo Kajo, Dtk. 1925. Riwajat Nan Toengga Magé' Djabang. Fort de Kock: Lie.

Bahar, Mahdi. 1997. "Pertunjukan salawat talam untuk membangun mesjid", Seni V/02-03: 225-234.

Bakar, Djamil, et al. 1979. Kaba Minangkabau. Jakarta: Pusat Pembinaan dan Pengembangan Bahasa, Departemen Pendidikan dan Kebudayaan. Two vols.

Bangun, Jabatin, et al. 1999. "Program pemetaan bahasa Nusantara, komite media elektronik, sub komite industri rekaman". Laporan penelitian, PMB LIPI and the Ford Foundation.

Barendregt, Bart. 2002. "The sound of 'longing for home'; Redefining a sense of community through Minang popular music", Bijdragen tot de Taal-, Land-en Volkenkunde 158/3: 411-450.

Barendregt, Bart and Wim van Zanten. 2002. "Popular music in Indonesia since 1998, in particular fusion, Indië and Islamic music on video compact discs and the internet", 2002 Yearbook for Traditional Music 34: 67-113.

Birch, David; Tony Schirato, and Sanjay Srivastava. 2001. Asia; Cultural politics in the global age. New York [etcetera]: Palgrave.

Bos, Paula R. 2005. "Nagi music and community", in: Hae-kyung Um (ed.), 
Diasporas and interculturalism in Asian performing arts; Translating traditions, pp.144-158. London [etcetera]: RoutledgeCurzon. [Routledge-Curzon-IIAS Asian Studies Series.]

Brooshooft, Pieter. 1892. "De nieuwe phonograph", De Locomotief (3 June).

Darma Putra, I Nyoman. 2004. "Politik lagu pop Bali", in: I Wayan Ardika and I Nyoman Darma Putra (eds), Politik kebudayaan dan identitas etnik, pp. 315337. Denpasar: Fakultas Sastra Universitas Udayana, Balimangsi Press.

Djamaris, Edwar. 2004. Kaba Minangkabau; Ringkasan isi cerita, tema dan amanat. Jakarta: Pusat Bahasa, Departemen Pendidikan Nasional.

Djamin and Tasat gl. S. Bagindo. 1934. Sjair Anggoen Tji' Toenggal. Batavia: Balai Poestaka.

Ediwar. 2003. "Tradisi baindang dan pengaruh budaya Islam di pesisir Sumatra Barat", in: Nasrul Azwar (ed.), Menyulam visi: DKSB dalam catatan, pp. 404-422. Padang: Dewan Kesenian Sumatra Barat.

Ediwar. 2007. Indang Pariaman; Dari tradisi surau ke seni pertunjukan rakyat Minangkabau. Bandung: P4ST Universitas Pendidikan Indonesia.

Finnegan, Ruth. 1977. Oral poetry; Its nature, significance and social context. Cambridge [etcetera]: Cambridge University Press.

Firman, Yandri. 1992. "Bagurau: analisis struktur". BA thesis, Universitas Andalas.

Hasselt, A. L. van. 1883. "De pidato bij de feesten der Minangkabo-Maleiers", in: Th. Ch. L. van Wijnmalen (ed.), Bijdragen tot de Taal-, Land-en Volkenkunde van Nederlandsch-Indië, ter gelegenheid van het Zesde Internationale Congres der Orientalisten te Leiden; Vol 1: Taal en Letterkunde, pp. 228-236.' s-Gravenhage: Nijhoff.

Junus, Umar. 1984. Kaba dan sistem sosial Minangkabau; Sebuah problema sosiologi sastra. Jakarta: Balai Pustaka.

Junus, Umar. 1994a. "Kaba; An unfinished (his-)tory", Tonan ajia kenkyu (Southeast Asian Studies) 32-3: 399-415.

Junus, Umar. 1994b. “Kaba as a text”, Masyarakat Indonesia 21-1: 95-110.

Kam, Garrett. 1987. "From court to cassette; The influence of the commercial recording industry on Javanese classical dance", UCLA Journal of Dance Ethnology 11: 39-44.

Kartomi, Margareth J. 1972. "Tiger capturing music in Minangkabau, West Sumatra", Sumatra Research Bulletin 2-1: 24-41.

Kartomi, Margareth J. 1981. "Randai theatre in West Sumatra; Components, music, origins, and recent change", Review of Indonesian and Malaysian Affairs 15-1: 1-44.

Kartomi, Margareth J. 1986. "Muslim music in West Sumatran culture", The World of Music 28-3: 13-30.

Kasih, Media Sandra. 2008. "The oration of the Minangkabau pasambahan: An ethnolinguistic study", in: Rodolfo Jacobson (ed.), The pulse of a Malaysian university: ethno- and sociolinguistic issues and the TESOL dimension, pp. 1122. New York [etcetera]: Peter Lang.

Koto, Hadjizar. 2003. "Perkembangan tradisi musik rabab di pesisir 
Minangkabau", in: Nasrul Azwar (ed.), Menyulam visi: DKSB dalam catatan, pp. 383-403. Padang: Dewan Kesenian Sumatra Barat.

Latrell, Craig. 1999. "Widening the circle; The refiguring of West Sumatran randai", Asian Theatre Journal 16-2: 248-259.

Lord, Albert B. 2003. The singer of tales. Second edition. Cambridge [etcetera]: Harvard University Press. [First edition 1960.]

Mahkota, Ambas. 1962. Anggun nan Tongga Magek Djabang dengan Puti Gondoriah. Bukittinggi: Pustaka Indonesia.

Manuel, Peter. 1993. Cassette culture; Popular music and technology in North India. Chicago/London: University of Chicago Press.

Mulyadi et al. 2008. Ensiklopedia sastra Minangkabau. Padang: Balai Bahasa Padang.

Naim, Mochtar. 1979. Merantau; Pola migrasi suku Minangkabau. Translated by Rustam St. R. Tinggi and Ansari. Yogyakarta: Gadjah Mada University Press.

Navis, A.A. 1984. Alam terkembang jadi guru; Adat dan kebudayaan Minangkabau. Jakarta: Grafitipers.

Ophuijsen, Ch.A. (ed). 1896. Kăbar si Omboet Moedå; Eene Minangkabausche vertelling. Leiden: Trap.

Pätzold, Uwe Umberto. 2004. “When the 'dampeang' is over, the 'luambek' is over; Sound as a determinant of structure within a competition of inner power based on movement in West Sumatra". Paper, The XXIII Symposium of the ICTM Study Group on Ethnology, Monghidoro, Italy, 13 July.

Pauka, Kirstin. 1998. Theater and martial arts in West Sumatra; Randai and silek of the Minangkabau. Athens, Ohio: Ohio University Press. [Monograph in International Studies Southeast Asia Series 103.]

Phillips, Nigel. 1979. "Pantun in sijobang", Indonesia Circle 19: 12-20.

Phillips, Nigel. 1981. Sijobang; Sung narrative poetry of West Sumatra. Cambridge: Cambridge University Press.

Phillips, Nigel. 1991. “Two variant forms of Minangkabau kaba”, in : J.J. Ras and S.O. Robson (eds), Variation, transformation and meaning; Studies on Indonesian literatures in honour of A. Teeuw, pp. 73-86. Leiden: KITLV Press.

Phillips, Nigel. 1992. "A note on the relationship between singer and audience in West Sumatran story-telling", Indonesia Circle 58: 67-70.

Postill, John R. 2006. Media and nation building; How the Iban became Malaysian. New York/Oxford: Berghahn Books.

Rodgers, Susan. 1986. "Batak tape cassette kinship; Constructing kinship through the Indonesian national mass media", American Ethnologist 13-1: 23-42.

Rosa, Silvia. 1990. “Hubungan antara latar belakang budaya Minangkabau dengan sikap tokoh perantau; Pembicaraan psikologi dan sosiologi sastra terhadap drama Minang modern". BA thesis, Universitas Andalas.

Salim, Hadji A. 1935. Tjeritera isra dan mi'raj Nabi Muhammad Rasoeloellah Çalla'llahoe-'alayhi wa sallam. Bandoeng/Batavia-C: Soember Ilmoe. 
Slobin, Mark. 1982. Tenement songs; Popular music of the Jewish immigrants. Urbana: University of Illinois Press.

Sopiann, Agus. 2002. "Lima raksasa perusahaan rekaman Internasional di Indonesia", Pantau Tahun III No. 025: 40-47.

St. Radjo Endah, Sjamsoeddin. 1964. Siti Baheram; Kisah klassik Minang. Bukittinggi: Pustaka Arga.

Sulaiman, Syafruddin. 1989/1990. "Kesenian Indang di Minangkabau". Laporan penelitian, The Toyota Foundation.

Suryadi. 1993a. Rebab Pesisir Selatan; Cerita Zamzami dan Marlaini. Jakarta: Yayasan Obor Indonesia.

Suryadi. 1993b. Dendang Pauah; Cerita Orang Lubuk Sikaping. Jakarta: Yayasan Obor Indonesia.

Suryadi. 1994. "Indang; Seni bersilat lidah di Minangkabau", Seni IV/03: 226-239.

Suryadi. 1996. "Rabab Pariaman; Satu ragam seni bercerita di pesisir barat Minangkabau", Seni 5/1-2: 82-96.

Suryadi. 1998. "Rabab Pariaman", in: John McGlynn (ed.), Language and Literature, Indonesian Heritage Series Vol. 9, pp. 66-67. Singapore: Archipelago Press.

Suryadi. 2003a. "Minangkabau commercial cassettes and the cultural impact of recording industry in West Sumatra", Asian Music 32-2: 51-89.

Suryadi. 2003b. "Children's pop music and the Indonesian regional recording industry; Minangkabau case". Paper, The KITLV Workshop on Southeast Asian Pop Music in a Comparative Perspective, Leiden, 8-12 December.

Suryadi. 2005. "Identity, media and the margins; Radio in Pekanbaru, Riau (Indonesia)", Journal of Southeast Asian Studies 36 (1): 131-151.

Suryadi. 2006. "The 'talking machine' comes to the Dutch East Indies; The arrival of western media technology in Southeast Asia", Bijdragen tot de Taal-, Land-en Volkenkunde 162-2/3: 269-305.

Suryadi. 2007a. "The 'talking machine', mechanical sounds, and modern noise; The cultural ramifications of gramophone consumption in the Dutch East Indies". Paper, The Fifth International Convention of Asian Scholars (ICAS5), 'Sharing a future in Asia', Kuala Lumpur, 2-5 August.

Suryadi. 2007b. "Transnasionalisasi muzik Indonesia; Makna kultural dan fungsi sosiopolitik resepsi muzik pop Minang di Malaysia", Wacana Seni, Jurnal of Arts Discourse Universiti Sains Malaysia 6: 1-30.

Susanti, Elvi. 1992. "Sastra lisan batintin; Suatu tinjauan semantik". BA thesis, Universitas Andalas.

Sutton, R. Anderson. 1985. "Commercial cassette recordings of traditional music in Java; Implications for performers and scholars", The World Music 27-3: 23-43.

Taher, Agusli. 2008. "Membangun kesadaran baru pencipta karya musik populer Minang dalam dimensi kekinian". Paper, Diskusi Musik pop Minang, Komite Musik Dewan Kesenian Sumatera Barat, Padang, 30 Mei. 
Toorn, J.L. van der. 1879. “Babagai-bagai tjoerito nan dipitjajoi oerang Melaijoe Tanah-Darè' Alam Minangkabau (Verscheidene verhalen omtrent het bijgeloof van de Malaiers in het land Minangkabau)", Tijdschrift voor Indische Taal-, Land- en Volkenkunde van het Bataviaasch Genootschap van Kunsten en Wetenschappen 25: 441-459.

Toorn, J.L. van der (ed. and transl.). 1886. Tjindoer Mato: MinangkabauschMaleische legende. Batavia: Albrecht and Rusche.

Toth, Andrew. 1980. Recordings of the traditional music of Bali and Lombok. Ann Arbor: The Society for Ethnomusicology. [Special Series 4.]

Wallach, Jeremy. 2008. Modern Noise, Fluid genres; Popular music in Indonesia, 1997-2001. Madison, Wisconsin: University of Wisconsin Press.

Weintraub, Andrew Noah. 2004. Power plays; Wayang golek puppet theatre in West Java. Athens, Ohio [etcetera]: Institute of Southeast Asian Studies. [Southeast Asia Series 110.]

Wieringa, Edwin. 1997. "The kaba Zamzami jo Marlaini; Continuity, adaptation, and change in Minangkabau oral story-telling", Indonesia and the Malay World 73: 235-251.

Williams, Sean. 1989/1990. "Current development in Sundanese popular music", Asian Music 21-1: 105-136.

Winsted, R.O. (ed.). 1914. Hikayat Anggun Che' Tunggal.Singapore: Methodist Publishing House.

Witnayetti. 1992. "Sastra lisan rabab Pariaman". BA thesis, Universitas Andalas.

Wong, Deborah. 1995. "Thai cassettes and their covers; Two case histories", in: John A. Lent (ed.), Asian popular culture, pp. 43-59. Boulder: Westview Press.

Yampolsky, Philip. 1987. Lokananta; A discography of the National Recording Company of Indonesia, 1957-1985. Madison: Centre for Southeast Asian Studies, University of Wisconsin.

Yampolsky, Philip. 2003. "What is regional about Indonesian 'regional pop'?", Paper, The KITLV Workshop on Southeast Asian Pop Music in a Comparative Perspective, Leiden, 8-12 December.

Yurnaldi. 2000. "Syawir Sutan Mudo; Seniman tradisi yang langka”, Kompas Sabtu, 13 November. [Reprinted in: Nasrul Azwar (ed.), 2003, Menyulam visi; DKSB dalam catatan, pp. 325-328, Padang: Dewan Kesenian Sumatra Barat.]

Zuriati. 2006. Bataram; Sutan Pangaduan di pesisir Minangkabau. Padang: Andalas University Press. 